\title{
Crystallographic and Seismic Anisotropies of Calcite at Different Depths: A Study Using Quantitative Texture Analysis by Neutron Diffraction
}

\author{
Michele Zucali ${ }^{1,2}, *\left(\mathbb{C}\right.$, Daniel Chateigner ${ }^{3}(\mathbb{1})$ and Bachir Ouladdiaf ${ }^{4}(\mathbb{C}$ \\ 1 Dipartimento di Scienze della Terra, Università degli Studi di Milano, 20133 Milano, Italy \\ 2 Department of Earth and Atmospheric Sciences, University of Houston, Houston, TX 77004, USA \\ 3 Laboratoire de Cristallographie et Sciences des Matériaux (CRISMAT), Ecole Nationale Supérieure \\ d'Ingénieurs de Caen University of Caen, 14050 Caen, France; daniel.chateigner@ensicaen.fr \\ 4 Institut Laue-Langevin, 71 avenue des Martyrs CS 20156, 38042 Grenoble, France; ouladdiaf@ill.eu \\ * Correspondence: michele.zucali@unimi.it or mzucali@uh.edu
}

Received: 3 November 2019; Accepted: 23 December 2019; Published: 27 December 2019

\begin{abstract}
Eight samples of limestones and marbles were studied by neutron diffraction to collect quantitative texture (i.e., crystallographic preferred orientations or $\mathrm{CPO}$ ) of calcite deforming at different depths in the crust. We studied the different Texture patterns developed in shear zones at different depth and their influence on seismic anisotropies. Samples were collected in the French and Italian Alps, Apennines, and Paleozoic Sardinian basement. They are characterized by isotropic to highly anisotropic (e.g., mylonite shear zone) fabrics. Mylonite limestones occur as shear zone horizons within the Cenozoic Southern Domain in Alpine thrust-and-fold belts (Italy), the Briançonnais domain of the Western Alps (Italy-France border), the Sardinian Paleozoic back-thrusts, or in the Austroalpine intermediate units. The analyzed marbles were collected in the Carrara Marble, in the Austroalpine Units in the Central (Mortirolo) and Western Alps (Valpelline). The temperature and depth of development of fabrics vary from $<100{ }^{\circ} \mathrm{C}$, to $800{ }^{\circ} \mathrm{C}$ and depth from $<10 \mathrm{~km}$ to about $30 \mathrm{~km}$, corresponding from upper to lower crust conditions. Quantitative Texture Analysis shows different types of patterns for calcite: random to strongly textured. Textured types may be further separated in orthorhombic and monoclinic (Types A and B), based on the angle defined with the mesoscopic fabrics. Seismic anisotropies were calculated by homogenizing the single-crystal elastic tensor, using the Orientation Distribution Function calculated by Quantitative Texture Analysis. The resulting P- and S-wave anisotropies show a wide variability due to the textural types, temperature and pressure conditions, and dip of the shear planes.
\end{abstract}

Keywords: calcite; seismic anisotropy; texture; $\mathrm{CPO}$; thrust; shear zone; neutron diffraction; crust

\section{Introduction}

The quantification of the seismic response of rocks is a fundamental task in understanding Earth's structure, from the core to the surface [1]. The large-scale seismic experiments, now with high-resolution arrays, is the most used approach to image the Earth and to resolve the distribution of natural resources in-depth, e.g., water, ore minerals, and oil \& gas [2,3]. However, the interpretation of seismic images strongly relies on the knowledge of the seismic response of the anisotropic aggregates of minerals composing the rocks, which in turn is intimately related to the textures of rocks [4], as well as on their extrinsic shape preferred features [5]. In the last two decades, a great effort has been made to quantify the seismic response of natural aggregates, chiefly by using the 2-Dimensional approach of the EBSD (Electron Back Scattered Diffraction) to reconstruct the Orientation Distribution Function 
(e.g., [6-8]). Carbonate rocks occur at the Earth's surface and upper crust levels, as sedimentary cover, but can be found within the intermediate and lower crust, as marbles. Within the upper crust, the tectonic deformation often localizes within carbonate rocks, producing thrust-folds systems $[9,10]$. Though less diffuse within the metamorphic basements, carbonate rocks are known to be equally crucial at depth because they likely represent weak horizons, often separating tectonometamorphic units [11,12]. For these reasons, the knowledge of the texture and seismic response of carbonate rocks is essential to interpret seismic anisotropy at various depth within the crust [13]. Several works have been dedicated to studying the behavior of calcite single crystal, limestones, and marbles at different temperatures and pressures [14-19]. A general scheme of the expected textures has been developed, combining natural and numerical data (see [20] and references therein), but data are still needed. Moreover, virtually no work has been dedicated to combining the neutron diffraction textural data with the prediction of seismic velocities through the homogenization of the elastic tensor [21,22].

With this contribution, we aim at producing new data related to the textures of carbonate rocks. In particular, we aim at relating different pressure, temperature, and shear geometry conditions of deformation with the type of texture developed. We also aim at investigating the control of texture types on the seismic anisotropies. The presented study will hence provide a reference to interpret measured seismic anisotropy in the continental crust [23], where carbonate rocks might be also involved in accommodating shearing along mylonitic horizons.

For this aim, we selected carbonate rocks characterized by fabrics developed at different temperature and pressure conditions and different strain geometries, from pure to simple shear, representing some of the large number of possible combinations in naturally deformed rocks. The samples have been collected mainly in the Alpine system and display a various degree of planar fabrics, developed at different depths within the crust. In this contribution, we will produce new texture data to be included in the general scheme of texture development. Moreover, we will calculate the component of the seismic anisotropies due to the texture by homogenizing the stiffness tensor using the Orientation Distribution Function obtained with the Quantitative Texture Analysis. Finally, we will investigate the influence of the orientation of the foliation plane on the seismic anisotropy [24] at different depth in the crust and with different textures.

\section{Samples Description and Geological Setting}

Samples were collected in the French and Italian Alps, Apennines, and Paleozoic basement (Figure 1). Different locations (Figure 1) were chosen to sample carbonate rocks from different crustal levels, from upper/intermediate crust limestones to lower crust high-temperature marbles (Table 1).

Table 1. List of samples labels with Alpine geological domain, crustal position with depth in $\mathrm{km}$, temperature in ${ }^{\circ} \mathrm{C}$ and shear geometry. Labels are the same as used in Figures and text. See text for references on $\mathrm{P}, \mathrm{T}$ and shear geometry. Upper crust for depth $<10 \mathrm{~km}$ at $\mathrm{T}<300{ }^{\circ} \mathrm{C}$, intermediate crust for depth between 10 and $20 \mathrm{~km}$ and $\mathrm{T}$ between 300 and $400{ }^{\circ} \mathrm{C}$, and lower crust for depth $>20 \mathrm{~km}$ and $\mathrm{T}>400{ }^{\circ} \mathrm{C}$.

\begin{tabular}{ccccc}
\hline Label & Domain & Crustal Position & Temperature & Shear Geometry \\
\hline 01BAS & Helvetic-Dauphinoise & upper $(<3 \mathrm{~km})$ & $<100^{\circ} \mathrm{C}$ & no shear \\
02SOD & Southalpine & upper $(<5-7 \mathrm{~km})$ & $\approx 200^{\circ} \mathrm{C}$ & simple shear \\
03SA1 & Sardinia Basement & intermediate $(12-15 \mathrm{~km})$ & $\approx 350^{\circ} \mathrm{C}$ & pure shear \\
04STE & Austroalpine & intermediate $(15-20 \mathrm{~km})$ & $300-350^{\circ} \mathrm{C}$ & simple shear \\
$05 \mathrm{CC} 2$ & Briançonnaise & intermediate $(<15 \mathrm{~km})$ & $300-350{ }^{\circ} \mathrm{C}$ & pure $/$ simple shear \\
06P1 & Apuane Metamorphic Complex & lower $(25-30 \mathrm{~km})$ & $400-500^{\circ} \mathrm{C}$ & no shear \\
08VP3 & Austroalpine & lower $(>18-20 \mathrm{~km})$ & $700-800^{\circ} \mathrm{C}$ & pure $/$ simple shear \\
09MA1 & Austroalpine & lower $(20-24 \mathrm{~km})$ & $600-750^{\circ} \mathrm{C}$ & simple/pure shear \\
\hline
\end{tabular}




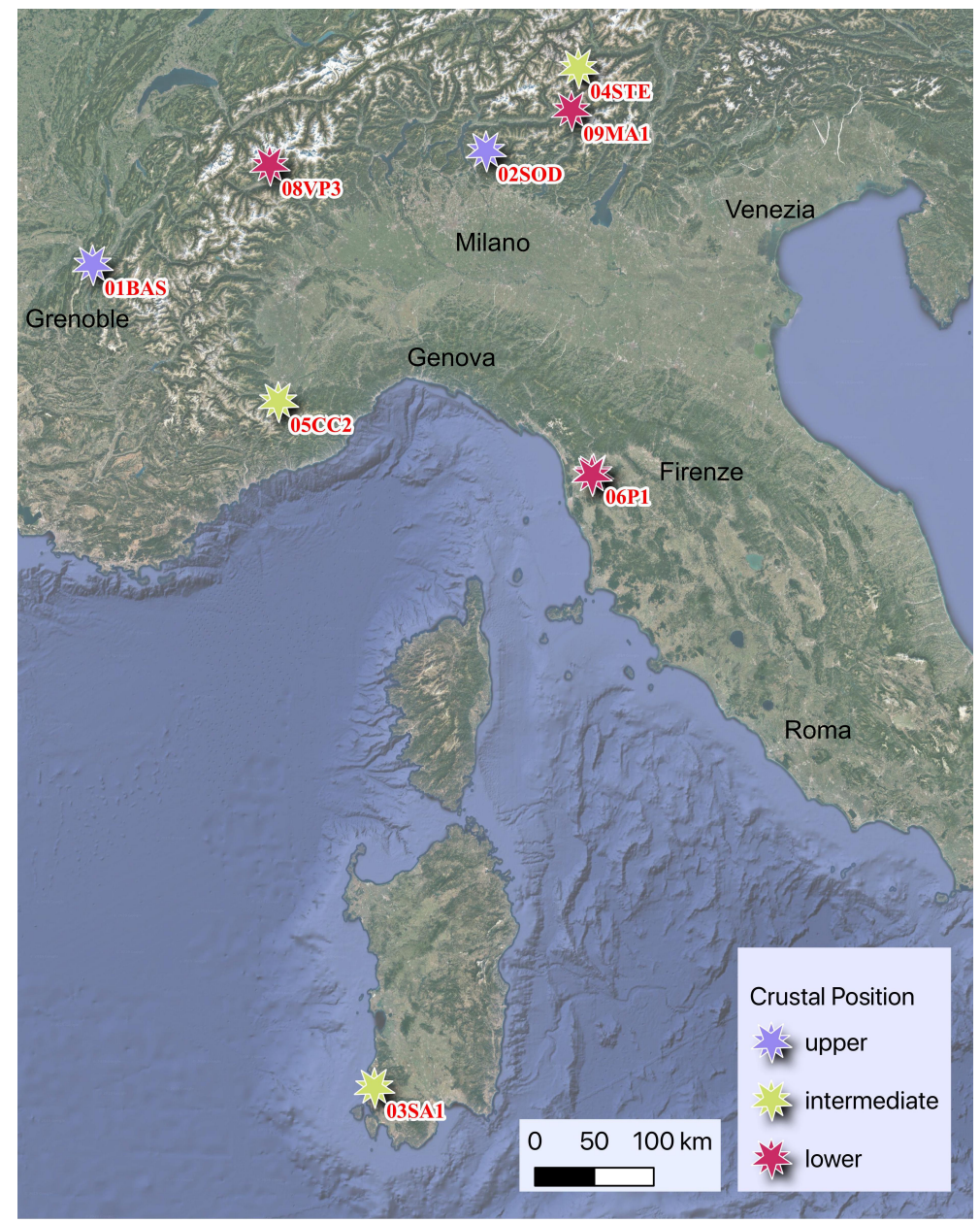

Figure 1. Location and crustal position of the studied samples, see text for explanation.

According to Figure 1, upper-crust samples were collected in the Southalpine domain, Sardinia and Helvetic-Dauphinoise (e.g., Triassic and Jurassic limestones). All samples preserve at macroscopic scale their primary features; intermediate crust samples were collected in the Briançonnais domain and in the Central Austroalpine domain, where Mesozoic sediments were involved in the Alpine tectonics at relatively upper levels. However, they still preserve their stratigraphic relations with the surrounding rocks, as sedimentary strata or laminations. The last group of samples, collected in the Carrara metamorphic complex, and in the Western-Central Austroalpine domain, are metamorphic marbles. In this last group, no sedimentary features are preserved.

- The BAS sample is a light gray crystalline limestone, fine-grained, homogeneous, and free of any planar fabrics at the macroscopic scale, both primary or secondary, as fractures or joints. It is Jurassic in age and it belongs to the External thrust-belt French Subalpine system [25,26]; it is part of the so-called Calcaires "tithoniques" [27]. It was sampled close to Grenoble (France), La Bastille, the southernmost part of the Chartreuse massive. According to the tectonic reconstruction and the local geologic map $[27,28]$, the thrust system developed a km-scale anticline, associated with brittle faults and fracture systems. The BAS sample has been collected within this anticline but far from the brittle system. The fold and thrust system occurred at $<3 \mathrm{~km}$ depth, at temperature $<100{ }^{\circ} \mathrm{C}$.

- The SOD sample was collected in the Southalpine domain. The sample is part of the Triassic cover, which crops along the entire Southalpine domain. The general interpretation infers the thrust and fold system to convergent tectonics active during the formation of the Alpine system (Figures 1 and 2). It was collected within the meter-scale mylonitic horizons associated with a meter to tens of meters asymmetric folds [29]. According to these authors, the thrust horizons 
occurred at relatively upper depth, not exceeding 5-7 km, corresponding to a maximum of $200{ }^{\circ} \mathrm{C}$. The studied sample shows an abrupt change in fabric from undeformed to highly strained domains (Figure 2), often associated with grain-size reduction, pressure-solution, and plastic deformation in carbonate grains, testified by mechanical twinning. These mesoand microstructures support temperatures as high as $200{ }^{\circ} \mathrm{C}[30,31]$. The kinematics of these thrust horizons have been reconstructed based on stratigraphic and structural constraints, being characterized by strong simple shear components also testified by classical shear indicators, as cmto $\mathrm{mm}$-scale drag folds and porphyroclasts geometries [32].

- $\quad$ SA1 sample was collected in the Sardinia basement. It is part of the Ceroidi Limestone (Gonnesa Fm.), pre-Ordovician protolith of the External Zone. This metasedimentary cover has been deeply involved in the Paleozoic-Variscan tectonics [33]. During the Variscan tectonic activity, green-schists metamorphic conditions were attained [34], locally associated with high strain shear horizons, from meters to tens of meters thick $[35,36]$. The SA1 sample was collected in one of these high strain horizons, made by meta-carbonate limestone. The Variscan deformation developed as pervasive folding systems. However, the SA1 sample was collected far from folds and within the domain where the mylonitic foliation is well visible at the macroscopic scale (Figure 2). As qualitative estimates for pressure and temperature, the intermediate limit can be put following the metamorphic evolution of the inner part of the belt, as described by Elter et al. [37]. Consequently, a limit of $350^{\circ} \mathrm{C}$ and $4-5 \mathrm{kbar}$, corresponding to roughly $12-15 \mathrm{~km}$ depth can be used to constrain the development of the fabric on this horizon. Moreover, mesoscopically no asymmetric shear sense indicators have been recognized, supporting the microstructural and textural observations [35], which suggested a pure shear strain.

- $\quad$ STE sample was collected in the Central Alps, within the intermediate Austroalpine domain [38]. Here the Mesozoic sedimentary cover was involved in the Alpine tectonics, occurring as thick-skinned thrusting of cover and its pre-alpine basement [39]. Thrusting localized along high strain horizons within cover and basement [40]. The temperature conditions of this event were estimated at $\mathrm{T}=300-350{ }^{\circ} \mathrm{C}$ at depth $=15-20 \mathrm{~km}[41,42]$. We collected a sample within the mylonite horizons in the Mesozoic cover, namely the Fraele Fm. It is characterized by a strongly developed mylonite fabric, associated with a meter- to tens of meter folds. A strong transposition of the lithostratigraphic features has been recorded along this horizon [43]. A simple shear component has been described for this deformation based on meso- and microstructural analysis [41]. Sample scale features, as mm-sized drag faults (Figure 2), support the simple shear component.

- CC sample was collected in the Western Alps, in the sub-Briançonnais domain. It consists of Jurassic limestone strongly deformed during Alpine thrusting of the external part of the chain [44]. According to [45,46] the External Briançonnais units equilibrated at a pressure not exceeding $5 \mathrm{kbar}$, corresponding to depths $<15 \mathrm{~km}$, and $\mathrm{T}=300-350{ }^{\circ} \mathrm{C}$. Moreover, overall simple shear kinematics is constrained by map- to micro-scale indicators, extensively described in the area [47-49]; however, the studied sample does not show clear microstructures that could be uniquely related to a simple shear geometry (Figure 2).

- P1 was collected in the well-known Carrara marbles quarries. They consist of the Mesozoic cover of the Autochthon of the Tuscan Units metamorphosed during the Alpine evolution [50,51]. $\mathrm{Km}$ - to meter-scale folding systems have been mapped, and several kinematics reconstructions have been proposed [52] suggesting large scale shear, related to the thrusting of the deep units, resulted in meso- and micro-scale simple shear fabrics (e.g., [20,53]). However, large scale strain partitioning also occurred, allowing a large volume of marbles to escape the development of planar or linear fabrics [54]. In fact, the studied sample is characterized by isotropic equigranular texture of recrystallized calcite (Figure 2), suggesting a static recrystallization process associated with grain-boundary migration both leading to grain size increase [32]. Within the Alpi Apuane 
Metamorphic Complex the estimated conditions of metamorphism point to $\mathrm{T}=400-500{ }^{\circ} \mathrm{C}$ at 8-10 kbar [50,55,56], corresponding to 25-30 km depth.

- VP3 and MA1 were both collected in the Austroalpine domain of the Alps [44]. The Austroalpine domain is interpreted as fragments of the pre-alpine continental crust involved in the Alpine subduction-collision system. The collected samples are marbles whose metamorphism has produced during high-temperature Permian-Triassic extension [57]. VP3 was collected in the Valpelline Series, Austroalpine of the Western Alps [58,59], while MA1 was collected in the Languard-Campo, Austroalpine domain of the Central Alps [60]. They are characterized by $0.5-1.5 \mathrm{~mm}$ (VP3) to $<0.5 \mathrm{~mm}$ (MA1) grain-size and strong planar fabric, marked by the shape preferred orientation of calcite and local diopside and quartz (Figure 2). They display diffuse mechanical twinning and undulose extinction, both suggesting grain-scale plastic deformation [32]. Shear indicators are not univocal, MA1 often shows asymmetrical bending of calcite tails around porphyroblast suggesting a component of simple shear, but pure shear cannot be ruled out. Similarly, VP3 displays a less tendency to develop asymmetric microstructures, point to a greater contribution of pure shear. Metamorphic conditions have been quantitatively determined for both samples, VP3 developed at $\mathrm{T}=700-800^{\circ} \mathrm{C}$ and $\mathrm{P}>6 \mathrm{kbar}$, corresponding to $>18 \mathrm{~km}$ depth, while MA1 fabric was estimated to form at $\mathrm{T}=600-750^{\circ} \mathrm{C}$ and $\mathrm{P}=6.5-7.5 \mathrm{kbar}$, corresponding to $20-24 \mathrm{~km}$ depth [58,60].

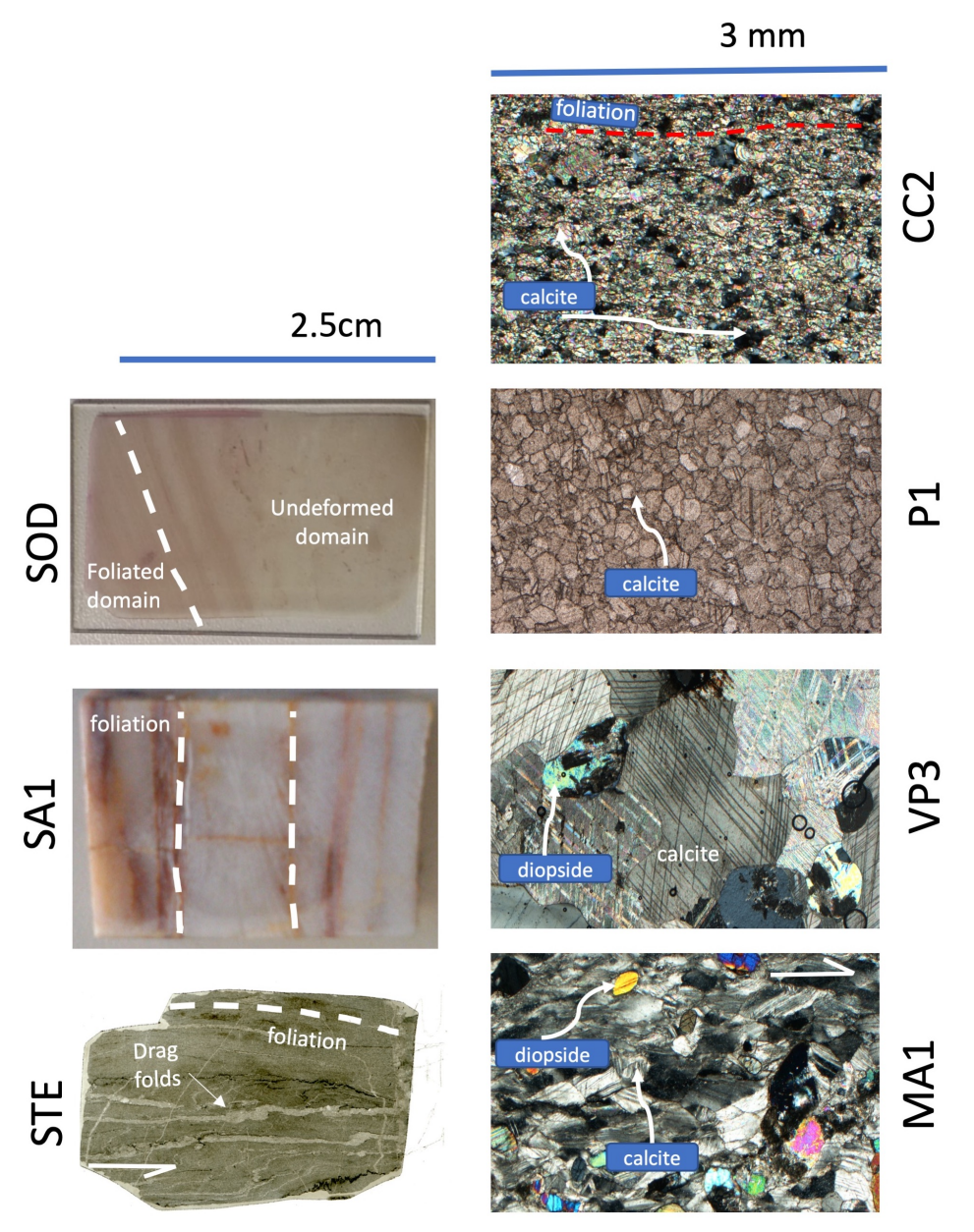

Figure 2. Images of selected samples showing main fabric features as layering or foliation. Scale is indicated. The long side of the image $2.5 \mathrm{~cm}$ for STE, SA1, and SOD; long side of the image is $3.0 \mathrm{~mm}$ for MA1, VP3, P1, and CC2. MA1, VP3, and CC2 images with crossed polarizers. P1 image with plane polarizers. 


\section{Sample Reference System and Methods}

The samples were cut in cubes of $\approx 1 \mathrm{~cm}$ edge (Figure 3); the three axes of the cube correspond to the orthonormal reference of the sample. In this orthogonal sample reference system, the plane $X Y$ corresponds to the stratification or shear plane, while $\mathrm{X}$ direction is taken parallel to the flow direction or lineation if it exists (Figure 3). The references in Figure $3 \mathrm{~b}$ are used in all the Pole figures (Figures 4-6). Pole figures display pole densities in multiples of a uniform distribution (mud).

\section{Sample Reference System}

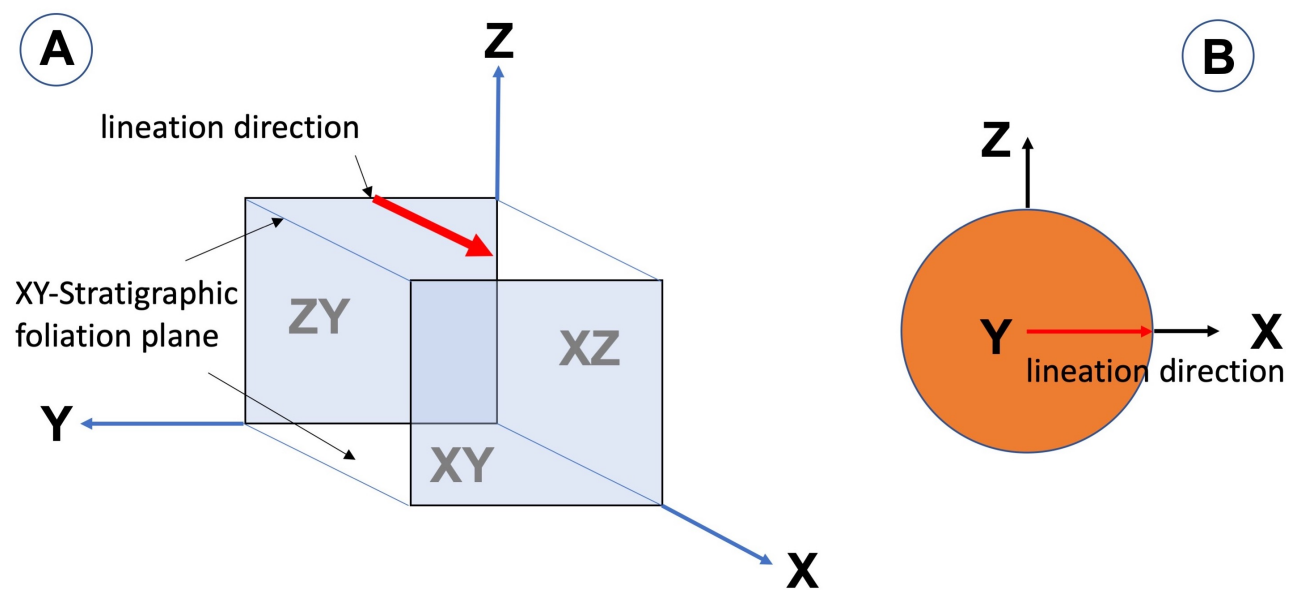

Figure 3. Sample reference system and pole figure representation. (A) sample reference system showing a simplified cubic sample with respect to the orthogonal reference. $X, Y$, and $Z$ axes are shown (B); Pole figure reference representation with $\mathrm{X}, \mathrm{Y}$, and $\mathrm{Z}$ axes.

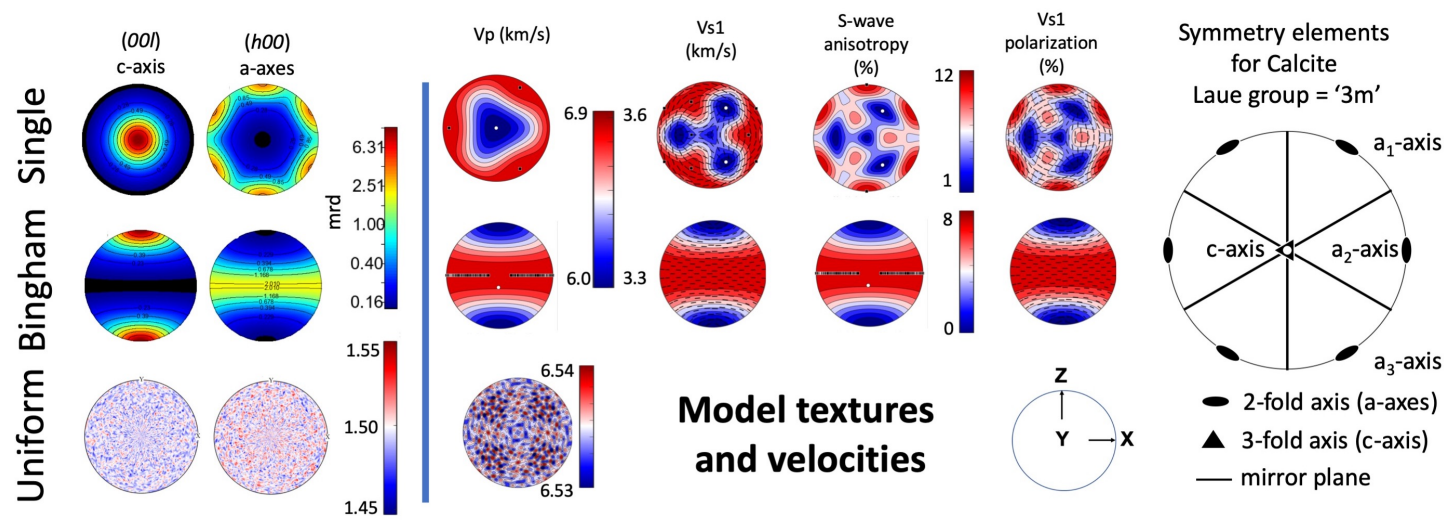

Figure 4. Pole figures for model textures and seismic velocities for single crystal-like, uniform, and bingham textured samples. Symmetry elements are shown for calcite crystal. 


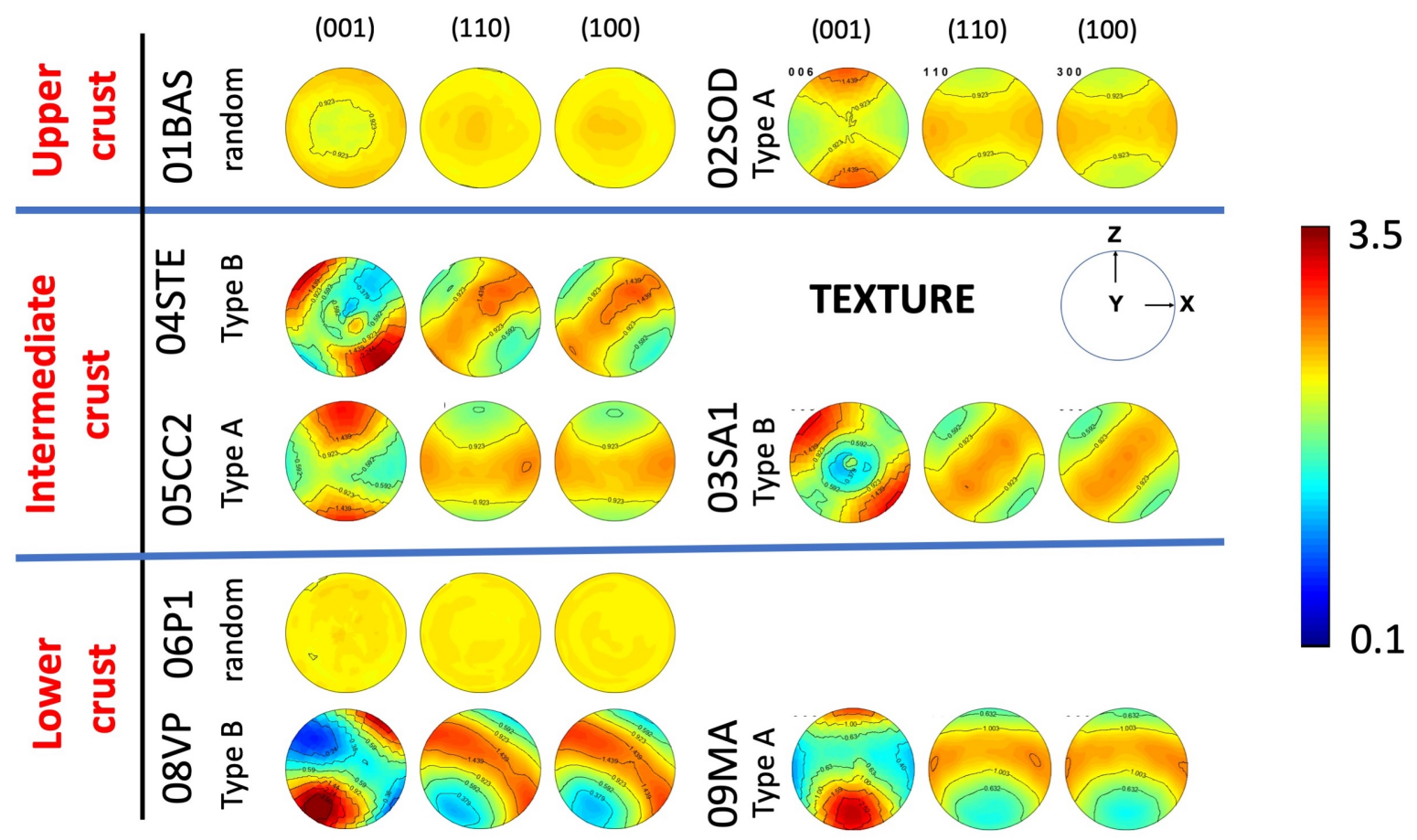

Figure 5. Texture of the studied sample. Pole figures represent density contours of poles to plane (001), (110), (100), in multiple of uniform distribution (mud). Axes reference as in Figure 3b.

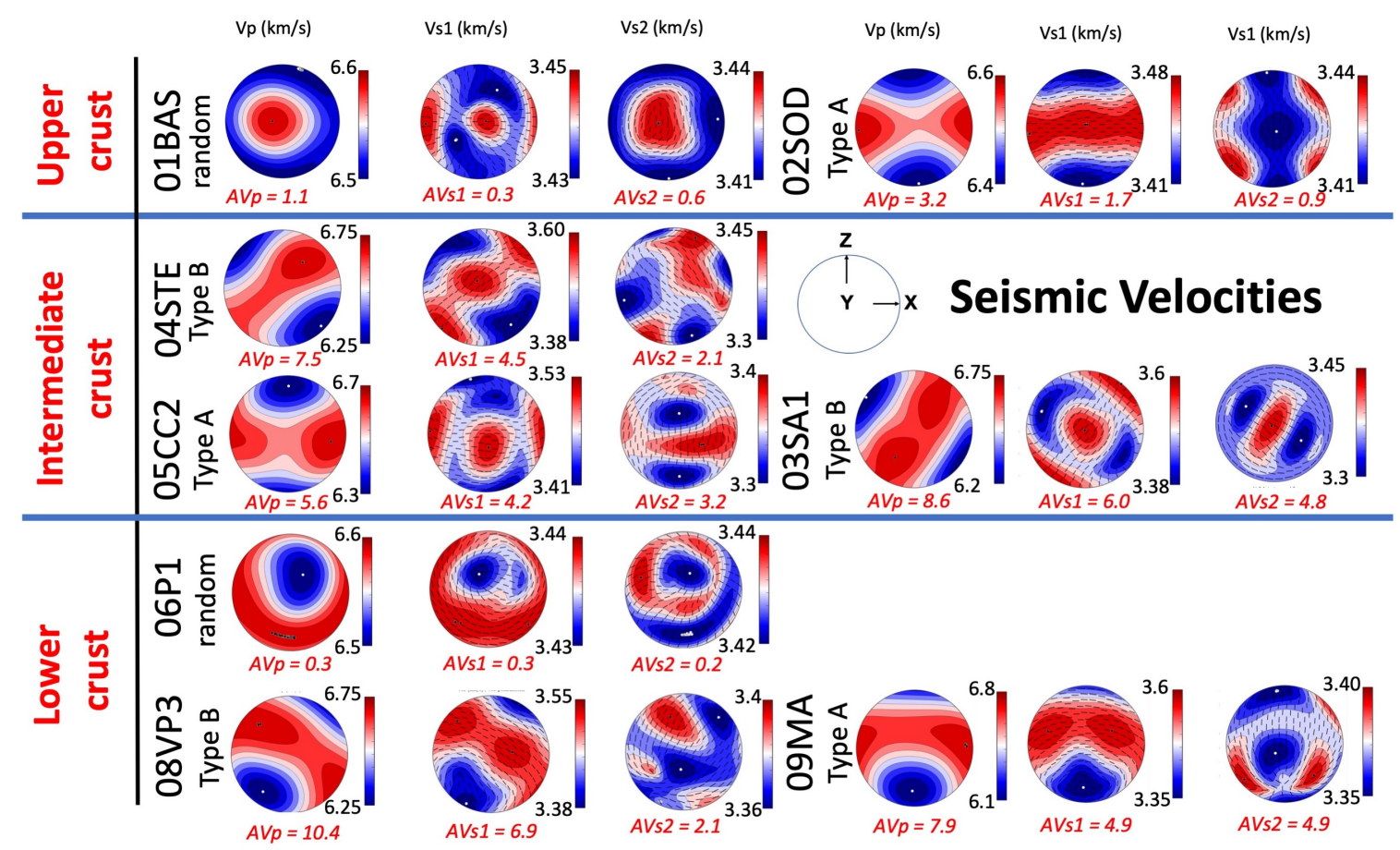

Figure 6. $\mathrm{Vp}(\mathrm{km} / \mathrm{s}), \mathrm{Vs} 1(\mathrm{~km} / \mathrm{s})$, and $\mathrm{Vs} 2(\mathrm{~km} / \mathrm{s})$ seismic waves velocities for the studied samples. Anisotropy for Vp (AVp), Vs1 (AVs1), Vs2 (AVs2) are calculated as A = 200 $(\operatorname{maxV}-\operatorname{mivV}) /(\operatorname{maxV}+$ $\min V)$. For $A V p V=V p$, for AVs1 V = Vs1, for AVs2 V = Vs2.

We used the non-disruptive method of the Quantitative Texture Analysis (QTA) by neutron diffraction. This method allows the evaluation of the Texture (also called Crystallographic Preferred Orientation, $\mathrm{CPO}$ ) of the samples. It has been successfully applied to various types of rocks and synthetic materials: monomineralic quartzites [61], marbles [20], limestones [62], dunite [63], 
or glaucophanite [64], in poly-phasic rocks, as amphibolite [65,66], quartz-feldspatic mylonitic orthogneisses and gabbros [67,68], subaqueous lavas [69] or sandstones [70]. This procedure uses the high penetration and high flux of neutrons available at the nuclear reactor at the Institute Laue-Langevin (Grenoble, France) allowing the measurement of samples with volumes of approximately $1 \mathrm{~cm}^{3}$ in one to eight hours [71]. Here, we present the results from the D1B, D19, and D20 diffractometers (http:/ / www.ill.eu). The raw data have been analyzed using the software package MAUD (Materials Analysis Using Diffraction [72]): diffracted intensities are used to calculate the Orientation Distribution Function (ODF [73]), from which the representative lattice planes are extracted and represented as Pole Figures (PF). PFs were represented showing the reference axes from the Sample Reference System (X, Y, Z in Figure 3). The coverage of the three-dimensional sample space has been acquired differently at the three beamlines (D1B, D19, and D19), due to their technical specifications. Briefly, D1B works at lambda $=2.52 \AA$, equipped with a position-sensitive detector, covering a $2 \theta$ range of $128^{\circ}$; D19 is equipped with a very large $\left(120^{\circ} \times 30^{\circ}\right)$ 2-dimensional position-sensitive detector, and works best in the wavelength range 0.8 to $2.4 \AA$; D20 offers wavelength range 1.4 to $2.1 \AA$ and the position sensitive detector covers $153.6^{\circ}$. The respective angular settings are reported in Table 2 . The ODF was calculated using the E-WIMV approach [73]. The reliability of the refinement is shown by the refinement parameters reported in Table 3. Calcite lattice parameters used for the refinements are a $=4.9849 \AA \mathrm{c}=17.0479 \AA$. 2Theta offset, sample position, and background parameters were also refined.

Table 2. ILL instrument, setup, and DOI. Acquisition time (s) refers to a single phi-chi position.

\begin{tabular}{cccccccc}
\hline Sample & Instrument & Year & $\boldsymbol{\omega}^{\circ}$ & $\boldsymbol{\phi}^{\circ}$ & $\chi^{\circ}$ & $\begin{array}{c}\text { Acquisition } \\
\text { Time (s) }\end{array}$ & $\begin{array}{c}\text { DOI } \\
\text { http://doi.ill.fr/10.5291/ILL-DATA }\end{array}$ \\
\hline 01BAS & D1B & 2016 & 10 & $0-355$ & $0-90$ & 20 & $1-02-201[74]$ \\
02SOD & D1B & 2016 & 10 & $0-355$ & $0-90$ & 20 & $1-02-201[74]$ \\
03SA1 & D19 & 2014 & 10 & $0-355$ & $0-90$ & 10 & $5-11-397[75]$ \\
04STE & D1B & 2016 & 10 & $0-355$ & $0-90$ & 20 & $1-02-163[76]$ \\
05CC2 & D1B & 2016 & 10 & $0-355$ & $0-90$ & 20 & $1-02-201[74]$ \\
06P1 & D1B & 2014 & 10 & $0-355$ & $0-90$ & 20 & no DOI \\
08VP3 & D20 & 2005 & 10 & $0-355$ & $0-90$ & 40 & no DOI \\
09MA1 & D20 & 2005 & 10 & $0-355$ & $0-90$ & 40 & \\
\hline
\end{tabular}

Table 3. Quantitative texture refinement parameters.

\begin{tabular}{cccccc}
\hline Sample & Rb Ref & Rexp Ref & Rw Rwimv & Rb Ewimv & $\mathbf{F}^{2}$-Texture Index \\
\hline 01BAS & 7.31 & 7.56 & 3.76 & 4.46 & 1.04 \\
02SOD & 24.6 & 5.93 & 2.9 & 4.0 & 1.10 \\
03SA1 & 27.19 & 25.62 & 24.11 & 24.43 & 1.732 \\
04STE & 19.6 & 6.24 & 9.53 & 9.59 & 1.6 \\
05CC & 9.22 & 3.96 & 4.11 & 4.57 & 1.26 \\
06P1 & 15.79 & 6.28 & 4.85 & 5.95 & 1.005 \\
08VP3 & 31.01 & 4.05 & 10.44 & 11.02 & 2.17 \\
09MA1 & 22.83 & 4.98 & 12.91 & 15.73 & 1.18 \\
\hline
\end{tabular}

The seismic properties were obtained using petrofabric data, as extensively explained by [7]. Here we calculated the sample seismic properties by averaging the single-crystal elastic tensor [77] weighted by the ODF, as obtained by quantitative texture analysis by neutron diffraction. In practice, the ODF calculated using the Maud procedure was used to homogenize the single-crystal tensor in Maud. Results for ODF refinements are reported in Table 3. Although various averaging procedures can be adopted [78], we used the arithmetic mean of Hill [79]. The resulting homogenized tensors (Table 4) were used in MTEX Matlab Toolbox [80] to compute and plot seismic properties [81] shown in Figure 6. The same averaged tensors have been then used to calculate the seismic anisotropies at different dip angles of the foliation plane, simply rotating the tensors and changing the plane of 
projection for the pole Figure in Figure 7. Pole Figures in Figure 7 are plotted in a way that only the Y-axis remains constant and the observer is looking down from the Earth's surface having the macroscopic foliation plane rotating with respect to the Y-axis.

Table 4. Homogenized elastic tensors for the studied samples-[GPa - density $=2.712 \mathrm{~g} / \mathrm{cm}^{3}$.

\begin{tabular}{|c|c|c|c|c|c|}
\hline \multicolumn{6}{|c|}{ Single Crystal } \\
\hline 124.80639 & 54.72449 & 51.150898 & 0 & -3.4680943 & 0 \\
\hline- & 124.80639 & 51.150898 & 0 & 3.4680943 & 0 \\
\hline- & - & 100.81746 & 0 & 0 & 0 \\
\hline- & - & - & 30.698822 & 0 & 3.4680943 \\
\hline- & - & - & - & 30.698822 & 0 \\
\hline- & - & - & - & - & 35.04095 \\
\hline \multicolumn{6}{|c|}{ Model Bingham } \\
\hline 127.50047 & 51.043633 & 55.929905 & 0 & 0 & 0 \\
\hline- & 96.653496 & 51.04301 & 0 & 0 & 0 \\
\hline- & - & 127.4964 & 0 & 0 & 0 \\
\hline- & - & - & 30.140978 & 0 & 0 \\
\hline- & - & - & - & 35.78422 & 0 \\
\hline- & - & - & - & - & 30.141603 \\
\hline \multicolumn{6}{|l|}{ 01BAS } \\
\hline 115.48373 & 51.741405 & 52.193005 & 0.0137869865 & -0.15203768 & -0.057538427 \\
\hline- & 115.00182 & 52.065735 & -0.015753072 & -0.070318885 & -0.06224491 \\
\hline- & - & 117.33802 & 0.003552162 & -0.22920334 & 0.008067851 \\
\hline- & - & - & 32.058846 & 0.005816382 & -0.07812717 \\
\hline- & - & - & - & 32.197884 & 0.013756884 \\
\hline- & - & - & - & - & 31.695593 \\
\hline \multicolumn{6}{|l|}{ 02SOD } \\
\hline 119.29561 & 51.75047 & 52.70474 & 0.09108701 & -0.13749328 & 0.24086875 \\
\hline- & 112.01606 & 51.493103 & 0.1646471 & -0.030619144 & 0.2721084 \\
\hline- & - & 116.93503 & 0.13448612 & -0.15284155 & 0.118958846 \\
\hline- & - & - & 31.385612 & 0.13175486 & -0.03567471 \\
\hline - & - & - & - & 32.75555 & 0.09919309 \\
\hline- & - & - & - & - & 31.68194 \\
\hline \multicolumn{6}{|l|}{ 03SA1 } \\
\hline 108.98519 & 51.129845 & 53.54879 & -0.22707361 & 0.09098859 & 4.010708 \\
\hline- & 115.68208 & 54.011932 & -0.42028734 & 0.19944625 & 4.040168 \\
\hline- & - & 120.24887 & -0.4792106 & 0.6209795 & 1.0868437 \\
\hline - & - & - & 34.00615 & 1.3028204 & 0.21294828 \\
\hline - & - & - & - & 33.391453 & -0.24855585 \\
\hline- & - & - & - & - & 30.711746 \\
\hline
\end{tabular}


Table 4. Cont.

\begin{tabular}{|c|c|c|c|c|c|}
\hline \multicolumn{6}{|l|}{ 04STE } \\
\hline 114.62599 & 51.28098 & 52.65128 & 0.40403882 & -0.24915834 & 4.076245 \\
\hline- & 113.24674 & 52.87957 & 1.7690595 & 0.1510593 & 2.9629822 \\
\hline - & - & 120.20226 & 1.3745261 & -0.33024174 & 1.3390523 \\
\hline- & - & - & 32.772617 & 1.5227332 & 0.12351844 \\
\hline- & - & - & - & 32.543037 & 0.45559624 \\
\hline - & - & - & - & - & 31.0105 \\
\hline \multicolumn{6}{|l|}{$05 \mathrm{CC} 2$} \\
\hline 120.331055 & 52.018433 & 53.357944 & -0.5572579 & 0.46192774 & -0.14939365 \\
\hline - & 109.84183 & 51.32877 & -2.052971 & 0.22327025 & -0.38076687 \\
\hline- & - & 117.142975 & -0.3637613 & 0.20798893 & 0.034985803 \\
\hline- & - & - & 31.15168 & 0.02339253 & 0.23576291 \\
\hline- & - & - & - & 33.43074 & -0.6357612 \\
\hline - & - & - & - & - & 31.877514 \\
\hline \multicolumn{6}{|l|}{ 06P1 } \\
\hline 116.18255 & 52.0272 & 51.979866 & -0.04868714 & -0.03236508 & -0.011777747 \\
\hline- & 116.03572 & 51.9618 & -0.16846395 & -0.021853263 & -0.021358635 \\
\hline- & 51.9618 & 115.6278 & -0.067962535 & -0.08895395 & -0.020873472 \\
\hline - & - & - & 31.94424 & -0.021930851 & -0.02458574 \\
\hline - & - & - & - & 31.965382 & -0.053988267 \\
\hline- & - & - & - & - & 32.021183 \\
\hline \multicolumn{6}{|l|}{ 07P2 } \\
\hline 117.62099 & 51.808167 & 52.04327 & 0.26321256 & 0.320841 & 0.538134 \\
\hline- & 115.71749 & 51.596924 & 0.7797489 & 0.24568443 & 0.40074456 \\
\hline- & - & 115.65552 & 0.5507176 & 0.31947044 & 0.02256278 \\
\hline- & - & - & 31.551678 & 0.03927036 & 0.26017663 \\
\hline - & - & - & - & 32.037464 & 0.29400057 \\
\hline- & - & - & - & - & 31.800737 \\
\hline \multicolumn{6}{|l|}{ 08VP3 } \\
\hline 117.58365 & 52.024033 & 53.17902 & 0.9461038 & 1.649634 & -5.2456484 \\
\hline- & 111.576004 & 52.19252 & 3.4886246 & 0.64441526 & -4.231288 \\
\hline- & - & 119.872314 & 3.4239075 & 1.0557145 & -1.510464 \\
\hline- & - & - & 31.833376 & -1.7366006 & 0.750887 \\
\hline - & - & - & - & 32.96562 & 1.1209756 \\
\hline- & - & - & - & - & 31.585485 \\
\hline \multicolumn{6}{|l|}{ 09MA1 } \\
\hline 123.13773 & 51.935154 & 53.12128 & 1.066385 & 0.72052747 & -0.34793347 \\
\hline- & 108.63644 & 51.16951 & 3.118211 & 0.10843302 & -0.30422294 \\
\hline- & - & 117.85145 & 3.0853832 & 0.26028427 & 0.001484112 \\
\hline - & - & - & 30.831026 & -0.014819718 & 0.1207543 \\
\hline- & - & - & - & 33.11233 & 1.2279662 \\
\hline- & - & - & - & - & 31.690102 \\
\hline
\end{tabular}




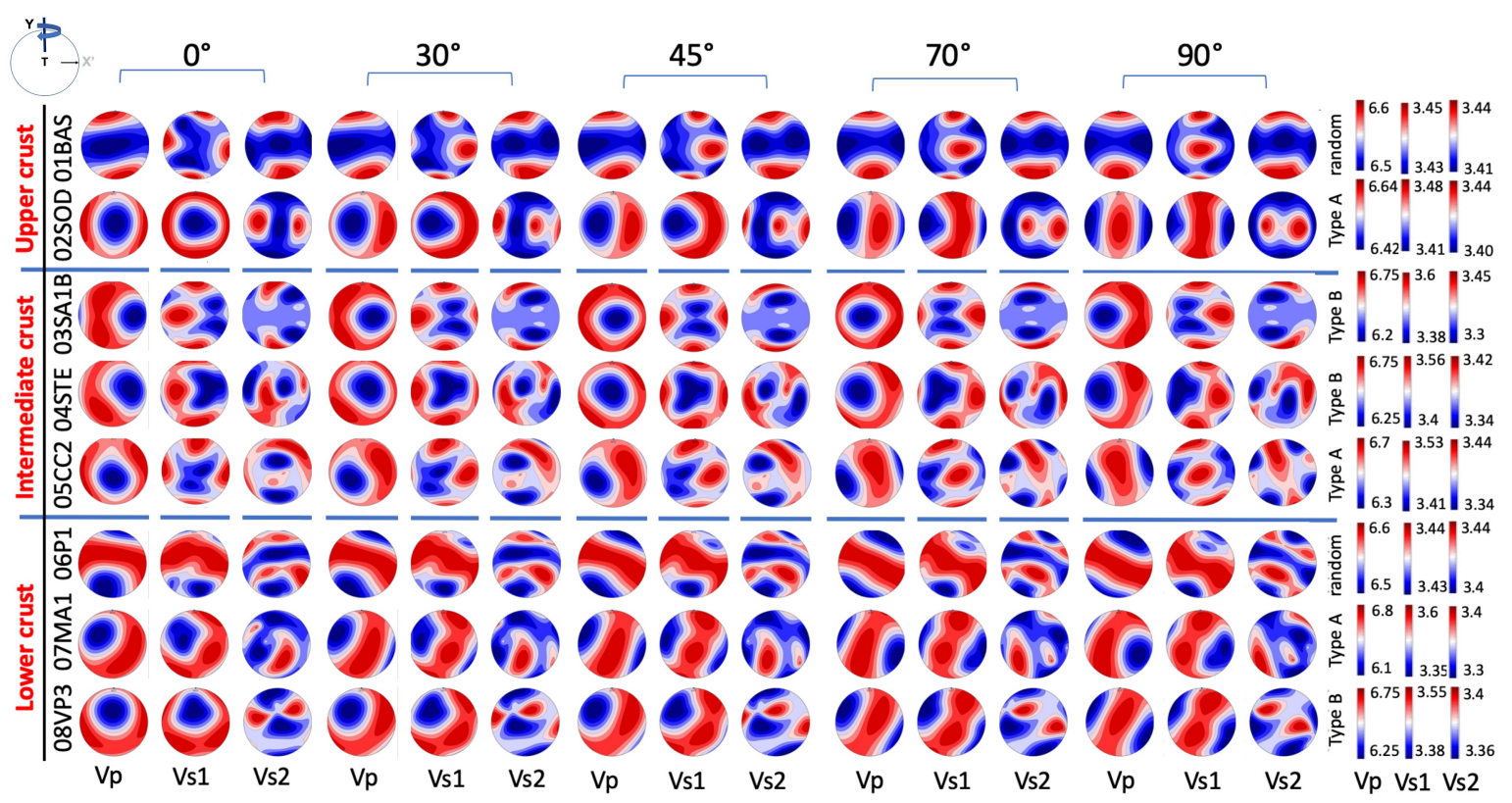

Figure 7. Pole figures representing the P- and S- (S1 and S2) seismic velocities for calcite at different depths and dipping angles to the main macroscopic fabric plane (e.g., shear plane or stratification). $\mathrm{X}^{\prime}$ corresponds to the horizontal component of the $\mathrm{X}$ fabric axis while $\mathrm{T}$ corresponds to the normal to the horizontal surface.

As a general consideration, this approach to computing seismic velocities generally produces higher values when compared to natural samples. The most likely reason for this is that other important factors, intrinsic and extrinsic, controlling seismic velocities, and anisotropies are not included in the calculation. These factors are fluid pressure, crack density and their orientation, porosity, grain boundary geometry, and their shape preferred orientation $[5,53,82,83]$.

A thermodynamic approach $[66,84]$ was also used to calculate the seismic properties of a modeled carbonate rock at different pressure and temperature conditions, roughly corresponding to the estimate conditions of texture development of the studied samples. We used the PerpleX software package (version 6.8.6 [85]) to compute the seismic parameters as dependent on the thermodynamic function $\mathrm{G}$ (molar Gibbs free energy), which is minimized to establish phases, amounts, and compositions stable as a function of pressure and temperature. The software requires a chemical composition of the system as input. Software and data used for the calculation of phase relations and seismic velocities are available at http:/ / www.perplex.ethz.ch. The graphical outputs were obtained using pyWerami source [86]. The calculated seismic properties correspond to those of a polycrystal rock with no preferred orientations. An averaged composition of carbonate rocks has been used as the model chemical system [87]. The model system composition (in wt \%) is: $\mathrm{SiO}_{2}=3.02, \mathrm{Al}_{2} \mathrm{O}_{3}=0.56$, $\mathrm{FeO}=0.39, \mathrm{MgO}=0.75, \mathrm{CaO}=52.40$. In the computation $\mathrm{CO}_{2}$ is considered saturated and, as solid solutions were chosen Do(HP) dolomite-ankerite solution, $\mathrm{M}(\mathrm{HP})$ for the magnesite-siderite solution, and Cpx(HP) clinopyroxene [88] and Perplex datafile repository. Holland and Powell (1998) [88] and successive update [89] (datafile hp62ver at http://www.perplex.ethz.ch/datafiles/) was used as a thermodynamic database. A typical output (Figure 8A) consists of pressure and temperature grid (in this calculation, $\mathrm{P}=1-15 \mathrm{kbar}$ and $\mathrm{T}=100-1000^{\circ} \mathrm{C}$ ) where the stable phases and assemblages are shown (i.e., pseudosection). Using the application Werami, which is part of the PerpleX package [85], specific properties were investigated in the P-T space and plotted in Figure 8B,C. Namely, we investigated the variations of modes, density, $\mathrm{Vp}$ and $\mathrm{Vs}$ of all phases within the investigated P-T ranges. Input data for PerpleX calculation may be found as Supplementary Materials. 

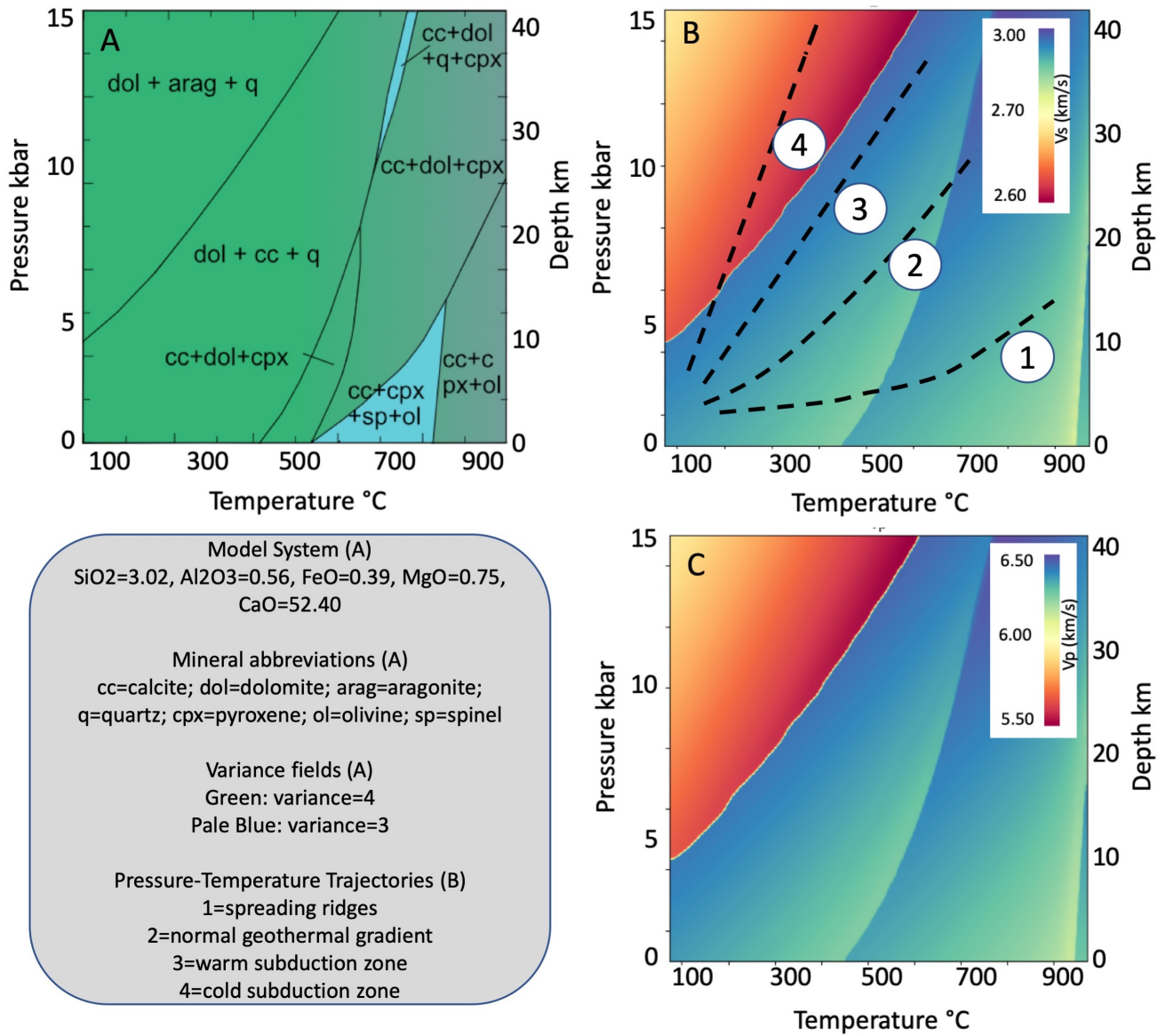

Figure 8. (A) Pseudosection calculated using Perple_X thermodynamic packages [85]. (B) Vs (km/s) seismic waves contour diagram. (C) $\mathrm{Vp}(\mathrm{km} / \mathrm{s})$ seismic waves contour diagram. Geothermal gradients in B after Cloos (1993) [90].

\section{Results}

\subsection{Textures}

Figure 4 reports the calculated PFs for a single crystal-like of calcite, an aggregate of equigranular randomly-disposed crystals, and an aggregate of equigranular grains, by a statistical Fisher-Bingham distribution.

They show the contributions to Texture expected by the crystallographic symmetry only or by textures: (i) single crystal distribution is characterized by a strong c-axis maximum and a three-fold axes distribution in the plane normal to the c-axis; (ii) oppositely, a random or uniform distribution of equigranular aggregate will reduce or obliterate the crystal symmetry anisotropy, producing a random statistical distribution, in any directions of the 3d space; (iii) lastly, an imposed (e.g., tectonic stress) distribution, here represented as the Fisher-Bingham distribution [91], will produce strong maxima that follow neither the crystal symmetry and nor a random distribution.

Figure 5 reports the pole Figures representing the lattice planes (001), (110), (100) texture measured for the studied samples. Calcite texture are commonly expressed showing c- and a-axes distributions (e.g., (001) and (100)) and m-planes (110) since these orientations better describe the deformation mechanisms active during plastic deformation at lattice scale and are commonly reported in the literature. Table 3 reports the $\mathrm{R}$ factors and $\mathrm{F}^{2}$ factor, commonly used in texture analysis to assess the quality of ODF refinement. In general, the samples show different texture distributions and densities but they can be divided into 2 principal types: a random distribution (01BAS, 06P1); c-axis textured distribution (02SOD, 03SA1, 04STE, 05CC2, 08VP, 09MA). The c-axis textured distribution may be further divided into orthorhombic (02SOD, 05CC2, 09MA) and monoclinic symmetry (03SA1, 04STE, 
05VP) types. The orthorhombic type (A) is characterized by the parallelism between the (001) poles and the $\mathrm{Z}$ direction. On the other hand, the monoclinic type (B) shows an angle between the (001) poles cluster and the Z-direction. Symmetrically, the (100) poles, which generally display a girdle distribution, may lay orthogonal to the $Z$ direction or with an angle, generally 30 to $45^{\circ} . \mathrm{F}^{2}$ values (Table 3) may be used as the overall index to assess the randomness of the texture [92,93]. As expected for poorly textured samples, 01BAS, 06P1 have $\mathrm{F}^{2}$ close to $1 \mathrm{mrd}^{2}$, even though 01BAS displays a minimum amount of preferred orientation. 02SOD, 04STE, 05CC2, and 09MA are characterized by well-developed textures, though the $\mathrm{F}^{2}$ index is relatively low, being between 1.10 and $1.26 \mathrm{mrd}^{2}$. Higher $\mathrm{F}^{2}$ values are shown by 03SA1 and 09MA.

\subsection{Seismic Velocities}

Figure 6 reports the calculated seismic velocities. Namely, P-wave Vp (km/s), S-wave anisotropy and Vs1 and V2 polarization. Their distributions closely resemble the main texture feature (Figure 5). In fact, since the c-axis direction is the slowest $\mathrm{Vp}$ in the single crystal setting, and the a-axes directions are close to fastest (Figure 3), the general feature that shows up is that the pole to (001) distribution correspond to the slowest directions in the Vp plots. So, the prediction of the slowest direction in carbonate rocks is relatively straightforward since it is influenced by the c-axis distribution. In contrast, $\mathrm{S}$-wave anisotropies are more complex to predict since they result from a combination of textures (Figure 5). Specifically, 02SOD, 06P1, 08VP, and 09MA display a girdle distribution of the poles to (100) and (110), which correspond to a pronounced direction of fastest propagation. Conversely, 01BAS, 03SA1, and 05CC2 are characterized by single or multiple clusters for S-wave anisotropies, giving a more complex pattern of polarization. 04STE displays a mixed distribution, where a weak fastest S-wave girdle links the two clusters.

\section{Discussion}

\subsection{Texture Types Evolution with Temperature, Pressure, Shear Geometry, and Strain}

Texture data reported in Figure 5 fall into the types of calcite texture most commonly described for natural rocks [94] and reported in experimental results [16,17,95,96]. In particular, we separated two types: random, where no or a little preferred orientation is found, and textured, characterized by a strong c-axis maximum and a-axes girdle distribution. Textured types have been further separated in Type A and Type B, to emphasize the relations between Texture and shear plane, as described for pure shear (i.e., orthorhombic geometry, Type A) and simple shear (i.e., monoclinic geometry, Type B) $[20,94,97]$. Type A and B have been used to infer the deformation regime and the sense of shear (e.g., [98-101]). However, Pieri et al. (2001) [102] demonstrated the risk of simplifying those textural relations with deformational regimes. In fact, the most common calcite deformation mechanisms may allow, even at low temperature, a quick transition from monoclinic to orthorhombic symmetries, even under a simple shear regime and at low strain $(>2)$. Similar observations have been made on naturally deformed marbles [103]. Accordingly, the studied samples also show that discriminating between high temperature (HT) and low temperature (LT) textures is not an easy task. For example, 02SOD, $05 \mathrm{CC} 2$, and $09 \mathrm{MA} 1$ samples, though their textures developed respectively at $\approx 200{ }^{\circ} \mathrm{C}, 300-350{ }^{\circ} \mathrm{C}$, and $600-750{ }^{\circ} \mathrm{C}$ (Table 1), they all display a similar orthorhombic symmetry; specularly, 04STE, 03SA1, 08VP share the same texture but developed at different temperatures, $300-350{ }^{\circ} \mathrm{C}, \approx 350{ }^{\circ} \mathrm{C}$, and $700-800{ }^{\circ} \mathrm{C}$ (Table 1). Literature data, between 100 and $400^{\circ} \mathrm{C}$ at increasing shear strain, suggest a general evolution from Type A texture, generally far from the shear zone core, to Type B textures and, more often, the coexistence of Type A and B [82]. Type A seems to become dominant at very high shear strain values and very high pressures $[16,104]$. At low temperature $\left(<300{ }^{\circ} \mathrm{C}\right)$ and low pressure $(<3 \mathrm{kbar})$, as in carbonate fault gouges or thrust systems, Type B is generally favorite [105-107] while $\mathrm{A}$ and $\mathrm{B}$ types start to compete where temperature, pressure, and shear strain all overcome certain thresholds. These threshold values are hard to quantify; most likely pressure should exceed 3-4 kbar 
and shear strain 1-2 [13,16,82,97,104,107]. Similar competing textures were also described for dolomite deforming between $240-300{ }^{\circ} \mathrm{C}$ under simple shear geometry [108]. Besides, the recent experimental work of Schuster et al. (2019) [16] shows that very high shear strains $(>80)$ tent to stabilize Type A texture that replaces early A or B types. This experimental work also strongly supports the findings by Ebert et al. (2007) [104] that constrained similar evolution from field observations. In particular, Ebert et al. (2007) [104] showed evolving random to Type A and B textures as temperature and shear strain increase. Ebert et al. (2007) [104] also showed textures similar to those of 04STE and 03SA1 samples where the angle between the c-axis maximum and the Z-axis is much higher than typically described.

Similar considerations may be done on metamorphic marbles produced at intermediate temperature $\left(\approx 400-600^{\circ} \mathrm{C}\right)$ and pressures related to subduction-collisional tectonics $(\approx 10-20 \mathrm{kbar})$. In particular, the large literature available on the Carrara Marble allows us to constrain textural types with shear strain geometry and grain size. Large $(1-2 \mathrm{~mm})$ to intermediate $(0.1-0.5 \mathrm{~mm})$ grain size marbles, characterized by granoblastic textures may show random texture $[53,109]$ as well as Type A [52]. The first most likely due to static annealing or larger scale strain-partitioning and the second associated with grain boundaries migration and subgrain rotation dynamic recrystallization processes [32]. In marbles showing shape preferred orientations and microscopic foliation, the Type A is better developed [20] suggesting a high shear strain condition. Experimental work on the Carrara marbles under torsion [110], ranging between 500 and $700{ }^{\circ} \mathrm{C}$ and shear strain from 0 up to 50, support the observations [111] that Type A easily stabilizes at high strain conditions replacing Type B, no matter if coaxial and non-coaxial. Again, this process seems to be more likely occurring at high temperatures $\left(>500{ }^{\circ} \mathrm{C}\right)$ [111]. Barnhoorn et al. (2004) [110] also showed that at low temperature $\left(\approx 500^{\circ} \mathrm{C}\right)$ random texture may replace Type $\mathrm{B}$ textures increasing shear strain. Other intermediate temperature marbles $\left(400-500{ }^{\circ} \mathrm{C}\right)$, from elsewhere (e.g., $\left.[11,103,112,113]\right)$ support this shift from B to A types texture. However, no shear strain constraints are available to include these observations in the above scheme. Higher temperature $\left(>600{ }^{\circ} \mathrm{C}\right)$ marbles, similar to samples 08VP3 and 09MA1, naturally [22] or experimentally [14,110] deformed do not show a strong shift from B to A type texture. These observations may be taken to support the idea that shear strain most likely controls the textural type, more than temperature. However, more observations are needed to build a valid general scheme. More observations are also needed to produce a solid scheme to relate deformation mechanisms with the observed textures. The texture observed in these samples does not uniquely relate to specific deformation mechanisms. Type A and B textures are present in samples where intra-crystalline slip mechanisms are relevant, as 08VP3 and 09MA1. On the other hand, where twinning is present, together with grain size reduction deformation mechanism (02SOD, 04STE, 05CC2), both Type A and Type B may develop [101]. Moreover, the combination of sub-grain rotation mechanisms, known to be important at similar conditions [16], and grain-boundary migration may have contributed to the observed random texture in P1.

\subsection{Seismic Anisotropy}

Seismic velocities and anisotropy of carbonate rocks in the studied samples change with texture types (Figure 6). Vp velocities vary from a minimum of $6.1 \mathrm{~km} / \mathrm{s}$ to a maximum of $6.8 \mathrm{~km} / \mathrm{s}$; AVp anisotropy varies between 0.3 and 10.4 (Figure 6). Vs varies from 3.3 and $3.6 \mathrm{~km} / \mathrm{s}$, while Vs1 anisotropy varies between 0.3 and 6.8. The direction of maximum $\mathrm{Vp}$ varies from parallel to $X$ direction of the fabrics (05CC2, 02SOD, 09MA), corresponding to Type A texture, to more than $45^{\circ}$ in the $\mathrm{XZ}$ plane (04STE, 03SA1, 06P1, 08VP3), for Type B texture. Vp displays a general girdle distribution that roughly describes a plane of max $\mathrm{Vp}$. Max Vp plane changes its orientation even within the same group of $\mathrm{Vp}$ max direction. Vp max in Type B samples has an angle with $X$ direction that varies between 20 to $50^{\circ}$. More interestingly, the $\mathrm{Vp}$ maximum frequently dips about $20-30^{\circ}$ away from the circumference (XZ plane). Similarly, the Vp max girdle plane dips between 20 to $50^{\circ}$ from the plane of shear. Besides, Vs velocities frequently show a double to triple maxima distributions. A large literature is available 
for sedimentary rocks, though the large majority is dedicated to shales and sandstones (see complete review [7]). Similar Vp and Vs values have been measured and calculated for calcite $[13,22,82,114,115]$ at different temperature and depth conditions. Vp velocities most frequently show a girdle distribution of maxima variably dipping to the plane of shear, recalling Type A and Type B distributions. In general, the $\mathrm{Vp}$ and Vs velocities overlap with those calculated for our samples, a part for those samples from very shallow depth $(<1000 \mathrm{~m})[114,115]$ where only after reducing porosity and increasing cementation the $\mathrm{Vp}$ values go from low $(<5 \mathrm{~km} / \mathrm{s})$ to higher values, more similar to those here measured and calculated $(>6 \mathrm{~km} / \mathrm{s})$. These observations support the general idea that carbonate rocks anisotropy also contributes to the overall anisotropy of the crust [7,22,82], at any depths. To further investigate the nature of these anisotropies we calculate the seismic isotropic component by the thermodynamic modeling described in chapter 3. The thermodynamic modeled seismic velocities, Vp and Vs (Figure 8), describe a range of $\mathrm{Vp}$ wave velocities from $\approx 6.0 \mathrm{~km} / \mathrm{s}$ to $6.5 \mathrm{~km} / \mathrm{s}$. Vs velocities vary from 2.6 to $3.0 \mathrm{~km} / \mathrm{s}$. The P-T plots in Figure 8B,C are characterized by three main parts where Vp and Vs vary progressively as a function of the changing mineral assemblages and mode proportion, as described in the pseudosection of Figure 8A. The three sectors are characterized by (i) the presence of aragonite instead of calcite a high pressure and low temperature; (ii) the association of calcite and dolomite at an intermediate temperature and pressure from low to high; (iii) the stabilization of clinopyroxene at high temperature, for low to high pressures. In general, $\mathrm{Vp}$ and $\mathrm{Vs}$ wave velocities decrease moving toward higher temperatures and increase moving toward higher pressures. According to the pressure and temperature constraints for the studied samples (Table 1) we are below the aragonite phase transition and the Vp should vary from 6.0 to $6.5 \mathrm{~km} / \mathrm{s}$, and Vs from 2.8 to $3.0 \mathrm{~km} / \mathrm{s}$. The calculated values from texture analysis $[68,84]$ as well as those reported in the literature, differ by about $10 \%$ from these calculated values. These values are generally closer to measured seismic velocities taken orthogonal to the maximum shear direction (i.e., lineation) [53] or in the more isotropic samples or very shallow sample, dominated by low porosity $(<10 \%)$ [115]. Consequently, these Vp and Vs can be used as a reference for the isotropic component of carbonate rocks, to investigate the amount of anisotropy to be expected when observing real seismic data for similar rock composition. In general, the analyzed samples show an increase of seismic velocities due only to textural anisotropies that can be about 0.2 to $0.8 \mathrm{~km} / \mathrm{s}$ for $\mathrm{Vp}$ and 0.3 to $0.6 \mathrm{Vs}$. These results show that seismic properties (e.g., velocities and anisotropies) even for a single rock type (e.g., carbonate rocks) may strongly change in the crust, as a function of temperature, pressure, and shear strain, as a result of texture types that strongly control seismic propagation. Similar considerations have been proposed for other rock compositions. In these rock types, specific mineral phases showed preferred orientations that produced relevant deviations from the isotropic component of the seismic properties (e.g., $[7,13,23,84])$. This evidence suggests that at depth there is important overlapping between different rock types in term of their seismic properties, such that unambiguous determination of geological information from natural seismic data imply a combined use of many parameters [116]. In addition, it is clear that also the orientation of the macroscopic fabric, shear foliation, lineation, or any fabric associated with texture in rock-forming minerals play an important role in defining seismic anisotropies [24,84].

To further investigate the relevance of the orientation of the shear plane at different depth in the crust, we used the approach of Ko and Jung (2015) [24] by rotating the shear flow plane around the Y-axis. In Figure 7 the results are shown by changing the plane of view, from XZ, used in Figures 3-6, to $X Y$. Figure 7 shows the progressive variations of the seismic properties by changing the dip angle from 0 to $90^{\circ}(0,30,45,70$, and 90). From the resulting rotated tensors, the components of Vp, Vs1, and Vs2 were read parallel to the horizontal component of the $X$ direction ( $X^{\prime}$ in Figure 7$)$, as well as parallel to the normal to the Earth's surface ( $T$ in Figure 7). Random textures are characterized by a constant $\mathrm{Vp}$ and Vs2 maxima parallel to the $\mathrm{Y}$ direction and the lowest direction being within the $X^{\prime} T$ plane (Figure 9). The lowest velocity is always recorded parallel to the vertical $T$ direction, at any dip. A relevant deviation is found for the Vs1 where the highest velocities parallel to $\mathrm{T}$ are recorded at dip $>45^{\circ}$, while parallel $X^{\prime}$ at dip $<45^{\circ}$ (Figure 9). Type A shows relatively similar 
features for samples at different depths, with a general trend with the $X^{\prime}$ component of $V p$ which decreases for steep dipping shear zones, while the $\mathrm{T}$ component increases, becoming the fastest at depth $>30-45^{\circ}$. The Vs1 component generally decreases for the three samples at different depths, but it is steeper for the lower crust sample (e.g., 08MA1). On the other hand, Vs2 components show that the intermediate crust sample $05 \mathrm{CC} 2$ has a different trend compared to the other samples. Type B has more diversification than Type A, Vp parallel to T may vary from slowest to fastest, independently by the dip. 08VP3 and 06P1 show the fastest values parallel to T at dip $>30^{\circ}$. Vs1 and Vs2 fastest are more commonly found at $Y$ for 03SA1 and 04STE intermediate crust samples, while in 06P1 Vs1 fastest velocities describe a girdle close to the $\mathrm{X}^{\prime} \mathrm{T}$ plane at any dip and in $08 \mathrm{VP} 3$ sample become closer to $\mathrm{T}$ at $\operatorname{dip}>45^{\circ}$. Vs2 velocities Vs2 fastest velocities are in the direction of Y for 03SA1 at any dip while they are highly variable for the sample 04STE. Girdles with maxima characterize Vs2 in 06P1 and 08VP3, producing highly heterogeneous distributions at different dips.

In the Type B distribution, the lower crust sample 09VP3 displays an opposite trend to the intermediate crust samples 03SA1 and 04STE. In particular, while for the intermediate crust samples the horizontal $\mathrm{Vp}$ and $\mathrm{Vs} 1$ values increase from 0 to $45-50^{\circ}$ and then decrease approaching vertical dipping, the lower crustal sample 08VP3 starts decreasing and then, at about $60^{\circ}$ dip, increases. These heterogeneities also occur for vertical Vp and Vs2 components. The Vp vertical component closely mirrors the $\mathrm{Vp}$ horizontal, while the Vs2 components are less sensitive to the dip variation, being in a smaller interval, generally $<0.1 \mathrm{~km} / \mathrm{s}$ (Figure 9).
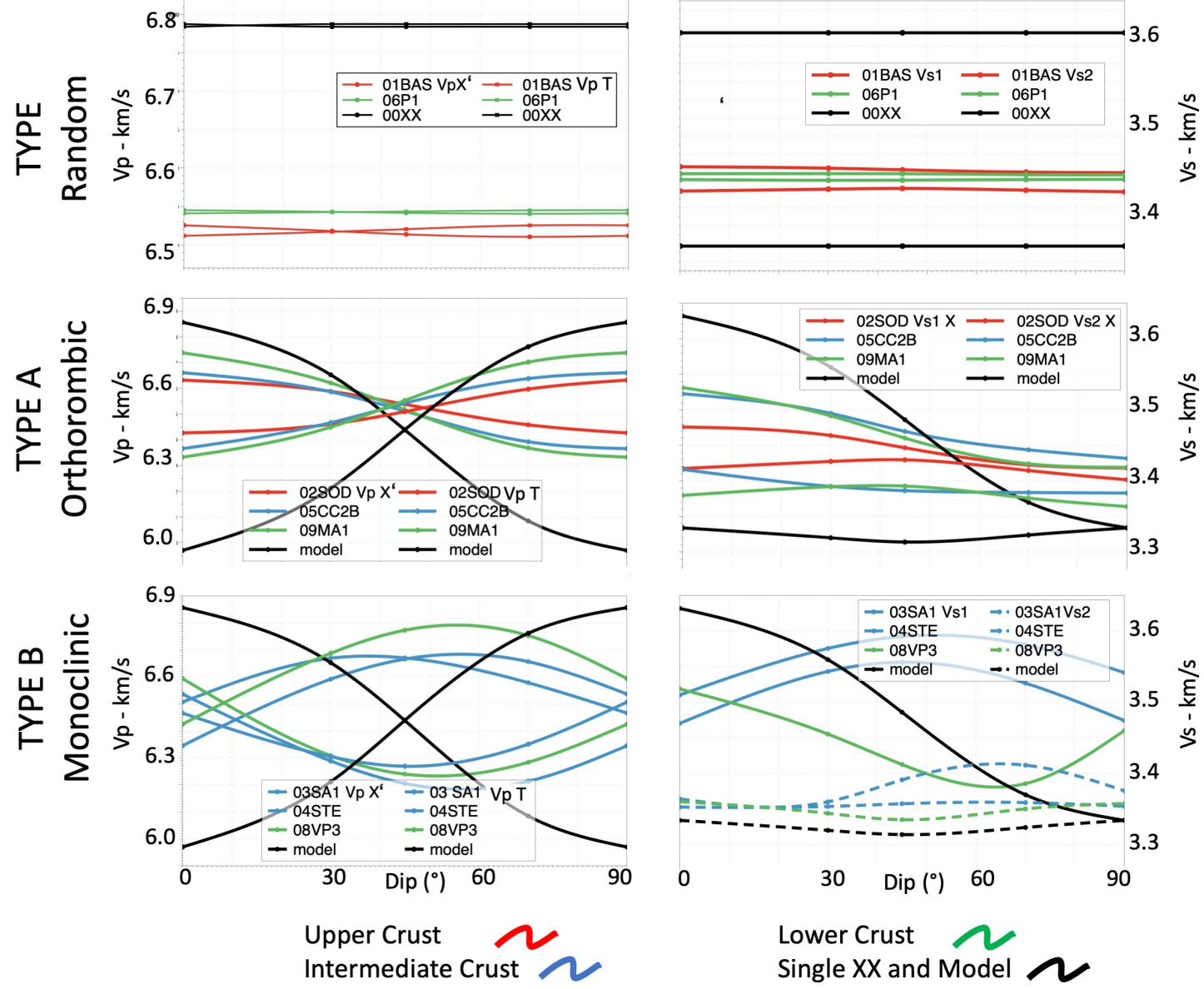

Figure 9. Vp components propagating horizontally ( $\mathrm{X}^{\prime}$ component) and vertically (T component)—Vs1 and Vs2 horizontal components. See text for explanation. 
Figure 10 represents the $\mathrm{Vp}$ velocities at different depths, at varying dip. From 0 to $15^{\circ}$ dipping of the shear planes, as those generally developed along the flat part of thrust systems [9], the Type A textures produce higher $V p$ velocities propagating horizontally, parallel to $X^{\prime}$ component (Figure 7) and slower parallel to the normal to the topographic surface (T component in Figure 7). This setting does not change with depth, while the fastest $\mathrm{Vp}$ velocities are recorded at depth (i.e., lower crust). This pattern is reversed at different dip angles: upper crust at $50^{\circ}$, intermediate crust between 20 and $30^{\circ}$, and the lower crust at $80^{\circ}$. At intermediate crust conditions, this flip may correspond to the evolution of the thrust system from flats to ramps. The change of dip corresponds to a substantial increase of $\mathrm{Vp}$ velocities parallel to $X^{\prime}$, from 6.4 to $6.7 \mathrm{~km} / \mathrm{s}$. At the same depths, it corresponds to a decrease parallel to $\mathrm{T}$ for rocks having a Type B texture pattern. Oppositely, at depth, both Type A and B produce an overall decrease of horizontally propagating velocities, from 6.8 to $6.3 \mathrm{~km} / \mathrm{s}$ and from 6.6 to $6.2 \mathrm{~km} / \mathrm{s}$, respectively. Type $B$ reaches its minimum at $50^{\circ}$ and then increases slowly approaching vertical dips. In general, steep dipping shear zones, as those in transtensional or transpressional systems (e.g., positive and negative flower structures), will produce slower or at maximum equal Vp velocities propagating horizontally $\left(X^{\prime}\right)$ than shear zone within the same system but with lower dipping angles (Figure 10). Figure 11 represents the evolution of Vp seismic velocities (vertical component $\mathrm{T}$ ) with depth at changing dip angles. Figure 11 also reports the predicted P-wave velocities in the continental crust as modeled by Lloyd et al. (2011) [23] for "rock recipes". Vertical red boxes correspond to Vp ranges for middle to lower crust proposed by Rudnick and Fountain (1995) [117]. Two aspects arise from this image. Firstly, carbonate rock may overlap with average rock types or "recipes" at various depth in the continental crust. Large discrepancies to these overlapping may arise by the dipping of the shear planes. At similar depths, $\mathrm{Vp}$ velocities may differ of about $0.3-0.5 \mathrm{~km} / \mathrm{s}$, only due to different dipping. Secondly, a specific pattern is reproduced by Type A texture, at any depth. The type A texture shows that it is characterized by an increase of $\mathrm{Vp}$ velocities as the dipping angle increases. This pattern is reproduced at the three different depths our samples represent. Moreover, Types B displays more variability in the way seismic velocities change with the dipping of the shear plane.

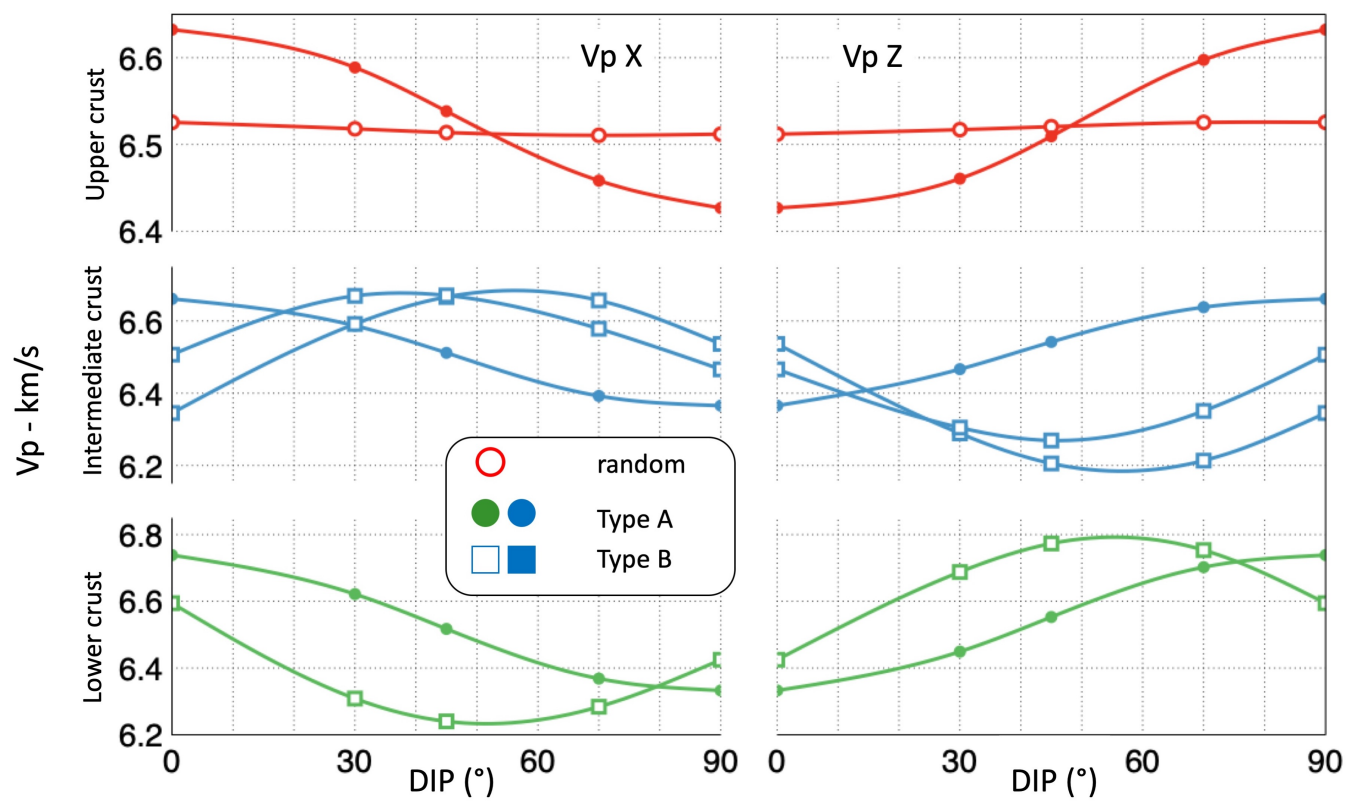

Figure 10. Vp crustal section. upper crust $=$ red, intermediate crust $=$ blue, lower crust $=$ green . Texture types: random $=$ hollow circle; $\mathrm{A}=$ circle; $\mathrm{B}=$ square. 


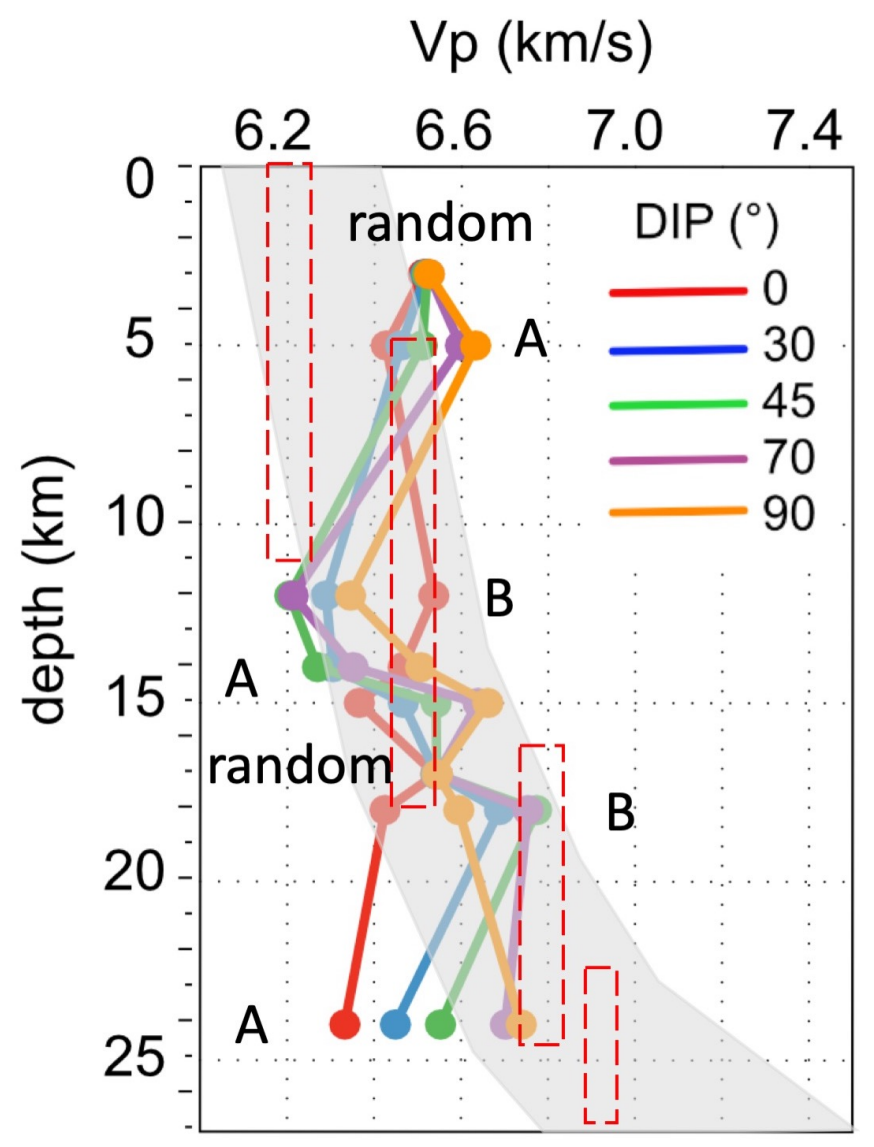

Figure 11. P-wave velocity propagating vertically (T component of Figure 7) crustal profile based on the data presented in this work for carbonate rocks at different depth and dip angle of the shear plane. Greys correspond to the predicted P-wave velocities in the continental crust as modeled by Lloyd et al. (2011) [23]. Vertical red boxes correspond to Vp ranges for middle to lower crust Rudnick \& Fountain (1995) [117]. Random, A and B texture Types described in the text.

\section{Conclusions}

- $\quad$ Eight samples of limestones and marbles were studied by neutron diffraction. We collected Texture of naturally deformed calcite at different depths in the crust, from upper to lower crust.

- Different Texture patterns were recognized, from random to strongly textured (Type B); the latter, with orthorhombic (Type A) or monoclinic (Type B) symmetries. Seismic anisotropies were calculated using the Orientation Distribution Function to homogenize the elastic tensor of calcite.

- A wide variability of seismic anisotropies arise from the various textural types, crustal positions, and dipping of the shear planes.

- These results may be valuably used to guess geometry of shear zones at upper to depth for carbonate rocks or at deeper crustal levels where thick carbonatic horizons are involved localizing deformation (Figure 11).

- This work suggests that at depth, even for carbonate rocks, there is an important overlapping between different rock types in term of their seismic properties (Figure 11); unambiguous determination of geological information from natural seismic must consider the orientation of the macroscopic fabric, shear foliation, lineation, or any fabric associated with texture playing a role in developing seismic anisotropies [24,84].

- More work still needs to be done to include other parameters influencing seismic anisotropies, intrinsic and extrinsic, to build a database of natural rocks properties [5-7,13,23]. 
- Lastly, texture types may produce unique seismic velocities pattern. For example, Type A (Figure 11) produces a unique pattern at any depth, characterized by an increase of Vp velocities (e.g., 6.3 to 6.8 at $20-25 \mathrm{~km}$ depth) as the dipping angle increases. Future studies may show if these singular patterns might be used to better constrain the interpretation of seismic profiles.

Supplementary Materials: The following are available online at http://www.mdpi.com/2075-163X/10/1/26/s1.

Author Contributions: All authors participated in the preparation of this manuscript. Sample Collection, M.Z.; Neutron Analysis, M.Z., D.C. and B.O.; Data Analysis, M.Z., D.C. and B.O.; Writing-Original Draft Preparation, M.Z; Writing-Review and Editing, M.Z., D.C. and B.O. All authors have read and agreed to the published version of the manuscript.

Funding: Neutron experiments were funded by ILL (www.ill.eu).

Acknowledgments: Two anonymous reviewers are greatly thanked for their help to produce the present form. This research is part of the MIUR Project: Dipartimenti di Eccellenza 2017-Le Geoscienze per la societa': risorse e loro evoluzione (Work-package 4, Task 4.3).

Conflicts of Interest: The authors declare no conflict of interest.

\section{References}

1. Lowrie, W. Fundamentals of Geophysics; Cambridge University Press: New York, NY, USA, 2007; 390p. [CrossRef]

2. Sun, L.; Fang, C.; Sa, L.; Yang, P.; Sun, Z. Innovation and prospect of geophysical technology in the exploration of deep oil and gas. Shiyou Kantan Yu Kaifa/Pet. Explor. Dev. 2015, 42, 414-424. [CrossRef]

3. Kendall, J.-M.; Fisher, Q.J.; Covey Crump, S.; Maddock, J.; Carter, A.; Hall, S.A.; Wookey, J.; Valcke, S.L.A.; Casey, M.; Lloyd, G.; et al. Seismic anisotropy as an indicator of reservoir quality in siliciclastic rocks. Geolog. Soc. Lond. Spec. Publ. 2007, 292, 123-136. [CrossRef]

4. Okaya, D.; Vel, S.S.; Song, W.J.; Johnson, S.E. Modification of crustal seismic anisotropy by geological structures ("structural geometric anisotropy"). Geosphere 2019, 15, 146-170. [CrossRef]

5. Faccenda, M.; Ferreira, A.M.; Tisato, N.; Lithgow-Bertelloni, C.; Stixrude, L.; Pennacchioni, G. Extrinsic Elastic Anisotropy in a Compositionally Heterogeneous Earth's Mantle. J. Geophys. Res. Solid Earth 2019, 124, 1671-1687. [CrossRef] [PubMed]

6. Brownlee, S.J.; Schulte-Pelkum, V.; Raju, A.; Mahan, K.; Condit, C.; Orlandini, O.F. Characteristics of deep crustal seismic anisotropy from a compilation of rock elasticity tensors and their expression in receiver functions. Tectonics 2017, 36, 1835-1857. [CrossRef]

7. Almqvist, B.S.; Mainprice, D. Seismic properties and anisotropy of the continental crust: Predictions based on mineral texture and rock microstructure. Rev. Geophys. 2017, 55, 367-433. [CrossRef]

8. Prior, D.J.; Mariani, E.; Wheeler, J. EBSD in the Earth Sciences: Applications, Common Practice, and Challenges. In Electron Backscatter Diffraction in Materials Science; Springer: Boston, MA, USA, 2010; pp. 345-360. [CrossRef]

9. Suppe, J. Geometry and Kinematics of fault-bend folding. Am. J. Sci. 1983, 283, 681-721. [CrossRef]

10. Smith, S.A.; Di Toro, G.; Kim, S.; Ree, J.H.; Nielsen, S.; Billi, A.; Spiess, R. Coseismic recrystallization during shallow earthquake slip. Geology 2013, 41, 63-66. [CrossRef]

11. Busch, J.P.; van der Pluijm, B.A. Calcite textures, microstructures and rheological properties of marble mylonites in the Bancroft shear zone, Ontario, Canada. J. Struct. Geol. 1995, 17, 677-688. [CrossRef]

12. Bestmann, M.; Kunze, K.; Matthews, A. Evolution of a calcite marble shear zone complex on Thassos Island, Greece: Microstructural and textural fabrics and their kinematic significance. J. Struct. Geol. 2000, 22, 1789-1807. [CrossRef]

13. Almqvist, B.S.; Hirt, A.M.; Herwegh, M.; Ebert, A.; Walter, J.M.; Leiss, B.; Burlini, L. Seismic anisotropy in the Morcles nappe shear zone: Implications for seismic imaging of crustal scale shear zones. Tectonophysics 2013, 603, 162-178. [CrossRef]

14. Barber, D.J.; Wenk, H.R.; Gomez-Barreiro, J.; Rybacki, E.; Dresen, G. Basal slip and texture development in calcite: New results from torsion experiments. Phys. Chem. Miner. 2007, 34, 73-84. [CrossRef] 
15. Pieri, M.; Kunze, K.; Burlini, L.; Stretton, I.; Olgaard, D.L.; Burg, J.P.; Wenk, H.R. Texture development of calcite by deformation and dynamic recrystallization at $1000 \mathrm{~K}$ during torsion experiments of marble to large strains. Tectonophysics 2001, 330, 119-140. [CrossRef]

16. Schuster, R.; Habler, G.; Schafler, E.; Abart, R. Microstructural and textural evolution of calcite deformed to high shear strain by high-pressure torsion. J. Struct. Geol. 2019, 118, 32-47. [CrossRef]

17. Schmid, S.M.; Panozzo, R.; Bauer, S. Simple shear experiments on calcite rocks: Rheology and microfabrics. J. Struct. Geol. 1987, 9, 747-778. [CrossRef]

18. Ferrero, A.M.; Migliazza, M.; Spagnoli, A.; Zucali, M. Micromechanics of intergranular cracking due to anisotropic thermal expansion in calcite marbles. Eng. Fract. Mech. 2014, 130, 42-52. [CrossRef]

19. Lutterotti, L.; Matthies, S.; Wenk, H.R.; Schultz, A.S.; Richardson, J.J.W. Combined texture and structure analysis of deformed limestone from time-of-flight neutron diffraction spectra. J. Appl. Phys. 1997, 81, 594-600. [CrossRef]

20. Leiss, B.; Molli, G. 'High-temperature' texture in naturally deformed Carrara marble from the Alpi Apuane, Italy. J. Struct. Geol. 2002, 25, 649-658. [CrossRef]

21. Matthies, S.; Humbert, M. On the Principle of a Geometric Mean of Even-Rank Symmetric Tensors for Textured Polycrystals. J. Appl. Crystallogr. 1995, 28, 254-266. [CrossRef]

22. Punturo, R.; Kern, H.; Cirrincione, R.; Mazzoleni, P.; Pezzino, A. P- and S-wave velocities and densities in silicate and calcite rocks from the Peloritani Mountains, Sicily (Italy): The effect of pressure, temperature and the direction of wave propagation. Tectonophysics 2005, 409, 55-72. [CrossRef]

23. Lloyd, G.E.; Butler, R.W.H.; Casey, M.; Tatham, D.J.; Mainprice, D. Constraints on the seismic properties of the middle and lower continental crust. Geol. Soc. Lond. Spec. Publ. 2011, 360, 7-32. [CrossRef]

24. Ko, B.; Jung, H. Crystal preferred orientation of an amphibole experimentally deformed by simple shear. Nat. Commun. 2015, 6, 1-10. [CrossRef]

25. Debrand-Passard, S.; Courbouleix, S.; Lienhardt, M. Synthèse Géologique du Sud-Est de la France; Mémoires BRGM: Orleans, France, 1984; pp. 1-125.

26. Courjault, T.; Grosheny, D.; Ferry, S.; Sausse, J. Detailed anatomy of a deep-water carbonate breccia lobe (Upper Jurassic, French subalpine basin). Sediment. Geol. 2011, 238, 156-171. [CrossRef]

27. BRGM. La Carte Géologique à 1/50000 GRENOBLE est Recouverte par la Coupure de la Carte Géologique de la France à 1/80000; BRGM: Orleans, France, 1970; 37p.

28. Jourdon, A.; Rolland, Y.; Petit, C.; Bellahsen, N. Style of Alpine tectonic deformation in the Castellane fold-and-thrust belt (SW Alps, France): Insights from balanced cross-sections. Tectonophysics 2014, 633, 143-155. [CrossRef]

29. Gaetani, M.; Sciunnach, D.; Bini, A.; Rossi, S. Foglio 076 Lecco. Note Illustrative Della Carta Geologica d'Italia alla Scala 1: 50.000; Servizio Geologico d'Italia: Ispra, Italy, 2012; Volume 5, 216 p.

30. Burkhard, M. Calcite twins, their geometry, appearance and significance as stress-strain markers and indicators of tectonic regime: A review. J. Struct. Geol. 1993, 15, 351-368. [CrossRef]

31. Ferrill, D.A.; Morris, A.P.; Evans, M.A.; Burkhard, M.; Groshong, R.H., Jr.; Onasch, C.M. Calcite twin morphology: A low-temperature deformation geothermometer. J. Struct. Geol. 2004, 26, 1521-1529. [CrossRef]

32. Passchier, C.; Trouw, R. Microtectonics; Springer: Berlin, Germany, 2005; Volume 275, 366p. [CrossRef]

33. Carmignani, L.; Oggiano, G.; Barca, S.; Conti, P.; Eltrudis, A.; Funedda, A.; Pasci, S.; Salvadori, I. Memorie Descrittive Della Carta Geologica D'Italia. Note Illustrative Della Carta Geologica Della Sardegna a Scala 1:200.000; Istituto Poligrafico e Zecca dello Stato: Roma, Italy, 2001; 283p.

34. Franceschelli, M.; Puxeddu, M.; Cruciani, G. Variscan metamorphism in Sardinia, Italy: Review and discussion. J. Virtual Explor. 2005, 1-35. [CrossRef]

35. Lebit, H. On Fold and Strain Interference Patterns in the Paleozoic Rocks of Iglesiente (SW Sardinia). Ph.D. Thesis, ETH Zurich, Zurich, Switzerland, 1995.

36. Carmignani, L.; Conti, P.; Funedda, A.; Oggiano, G.; Pasci, S. La geologia della Sardegna-Geological Field Tips. Geol. Field Trips 2012, 4, 104. [CrossRef]

37. Elter, F.M.; Corsi, B.; Cricca, P.; Muzio, G. The south-western alpine foreland: Correlation between two sectors of the variscan chain belonging to "stable Europe": Sardinia(-)Corsica and the Maures Massif (South-Eastern France). Geodin. Acta 2004, 17, 31-40. [CrossRef] 
38. Polino, R.; Dal Piaz, G.V.; Gosso, G. Tectonic erosion at the Adria margin and accretionary processes for the Cretaceous orogeny of the Alps. In Deep Structure of the Alps; Roure, F., Heitzmann, P., Polino, R., Eds.; Société Géologique de France: Mémoire, France, 1990; pp. 345-367.

39. Schmid, S.M.; Haas, R. Transition from near-surface thrusting to intrabasement decollement, Schlinig Thrust, Eastern Alps. Tectonics 1989, 8, 697-718. [CrossRef]

40. Conti, P.; Manatschal, G.; Pfister, M. Synrift sedimentation, Jurassic and Alpine tectonics in the central Ortler Nappe, (Eastern Alps, Italy). Eclogae Geol. Helv. 1994, 87, 63-90.

41. Conti, P. The Austroalpine Ortler Nappe and the Tectonic Evolution of the Engadine Dolomites (Switzerland-Italy); Istituto Poligrafico e Zecca dello Stato: Roma, Italy, 1997; Volume 53, 102p.

42. Berra, F.; Jadoul, F. Stratigraphy, paleogeography and tectonic setting of the Norian succession of the Ortles Nappe (Central Austroalpine, Lombardy, Northern Italy). Mem. Sci. Geol. Padova 1999, 51, 78-89.

43. Montrasio, A.; Berra, F.; Cariboni, M.; Ceriani, M.; Deichmann, N.; Ferliga, C.; Gregnanin, A.; Guerra, S.; Guglielmin, M.; Jadoul, F.; et al. Note Illustrative dalla Carta Geologica d'Italia alla scala 1:50.000 Foglio 24 CARG. ISPRA 2012, 24, 150.

44. Bigi, G.; Castellarin, A.; Coli, M.; Dal Piaz, G.V.; Sartori, R.; Scandone, P.; Vai, G.B. Structural Model of Italy, Sheets 1-2, Progetto Finalizzato Geodinamica; Società Geologica Italiana: Roma, Italy, 1990.

45. Piana, F.; Battaglia, S.; Bertok, C.; D’atri, A.; Ellero, A.; Leoni, L.; Martire, L.; Perotti, E. Illite (KI) and chlorite (AI) "crystallinity" indices as a constraint for the evolution of the External Briançonnais Front in Western Ligurian Alps (NW Italy). Ital. J. Geosci. 2014, 133, 445-454. [CrossRef]

46. Michard, A.; Avigad, D.; Goffé, B.; Chopin, C. The high-pressure metamorphic front of the south Western Alps (Ubaye-Maira transect, France, Italy). Schweiz. Mineral. Petrogr. Mitt. 2004, 84, 215-235.

47. Bertok, C.; Musso, A.; D'atri, A.; Martire, L.; Piana, F. Geology of the Colle di Tenda-Monte marguareis area (Ligurian Alps, NW Italy). J. Maps 2018, 14, 542-551. [CrossRef]

48. Carminati, E.; Gosso, G. Structural map of a Ligurian Briançonnais cover nappe (Conca delle Carsene, Monte Marguareis, Ligurian Alps, Italy) and explanatory notes. Mem. Soc. Geol. Padova 2000, 52-1, 93-99.

49. Carminati, E. Incremental strain analysis using two generations of syntectonic coaxial fibres: An example from the Monte Marguareis Briançonnias cover nappe (Ligurian Alps, Italy). J. Struct. Geol. 2001, 23, 1441-1456. [CrossRef]

50. Molli, G.; Giorgetti, G.; Meccheri, M. Tectono-metamorphic evolution of the Alpi Apuane Metamorphic Complex: New data and constraints for geodynamic models. Bolletino Della Soc. Geol. Ital. 2001, 1, 789-800.

51. Di Pisa, A.; Franceschelli, M.; Leoni, L.; Meccheri, M. Regional variation of the metamorphic temperatures across the Tuscanid I Unit and its implications on the alpine metamorphism (Apuan Alps, N-Tuscany). Neues Jahrb. Mineral. Abh. 1985, 151, 197-211.

52. Molli, G.; Conti, P.; Giorgetti, G.; Meccheri, M.; Oesterling, N. Microfabric study on the deformational and thermal history of the Alpi Apuane marbles (Carrara marbles), Italy. J. Struct. Geol. 2000, 22, 1809-1825. [CrossRef]

53. Burlini, L.; Kunze, K. Fabric and seismic properties of Carrara marble mylonite. Phys. Chem. Earth Part A Solid Earth Geod. 2000, 25, 133-139. [CrossRef]

54. Carmignani, L.; Conti, P.; Disperati, L.; Fantozzi, P.; Giglia, G.; Meccheri, M. Carta Geologica del Parco delle Alpi Apuane. Scala 1:50.000; SELCA: Firenze, Italy, 2000.

55. Molli, G.; Vitale Brovarone, A.; Beyssac, O.; Cinquini, I. RSCM thermometry in the Alpi Apuane (NW Tuscany, Italy): New constraints for the metamorphic and tectonic history of the inner northern Apennines. J. Struct. Geol. 2018, 113, 200-216. [CrossRef]

56. Carmignani, L.; Conti, P.; Cornamusini, G.; Pirro, A. Geological map of Tuscany (Italy). J. Maps 2013, 9, 487-497. [CrossRef]

57. Spalla, M.I.; Zanoni, D.; Marotta, A.M.; Rebay, G.; Roda, M.; Zucali, M.; Gosso, G. The transition from Variscan collision to continental break-up in the Alps: Insights from the comparison between natural data and numerical model predictions. Geol. Soc. Lond. Spec. Publ. 2014, 405, 363-400. [CrossRef]

58. Manzotti, P.; Zucali, M. The pre-Alpine tectonic history of the Austroalpine continental basement in the Valpelline unit (Western Italian Alps). Geol. Mag. 2013, 150, 153-172. [CrossRef]

59. Zucali, M.; Manzotti, P.; Diella, V.; Pesenti, C.; Risplendente, A.; Darling, J.; Engi, M. Permian tectonometamorphic evolution of the Dent Blanche Unit (Austroalpine domain, Western Italian Alps). Rend. Online Soc. Geol. Ital. 2011, 15, 133-136. 
60. Roda, M.; Zucali, M.; Li, Z.X.; Spalla, M.I. Pre-Alpine contrasting tectono-metamorphic evolutions within the Southern Steep Belt, Central Alps. Lithos 2018, 310-311, 31-49. [CrossRef]

61. Camana, G.; Chateigner, D.; Zucali, M.; Artioli, G. The grid-work texture of authigenic microcrystalline quartz in siliceous crust-type (SCT) mineralized horizons. Am. Mineral. 2002, 87, 1128-1138. [CrossRef]

62. Wenk, H.R. Neutron diffraction texture analysis. In Neutron Scattering in Earth Sciences, Reviews in Mineralogy and Geochemistry, Vol. 63; Mineralogical Society of America: Chantilly, VA, USA, 2006; pp. 399-426.

63. Zucali, M.; Tartarotti, P.; Capelli, S.; Ouladdiaf, B. Multiscalar structural study of the ultramafic rocks of the Antrona ophiolite (Pennine Alps). J. Virtual Explor. 2012, 41, 1-23. [CrossRef]

64. Zucali, M.; Chateigner, D.; Dugnani, M.; Lutterotti, L.; Ouladdiaf, B. Quantitative texture analysis of glaucophanite deformed under eclogite facies conditions (Sesia-Lanzo Zone, Western Alps); comparison between X-ray and neutron diffraction analysis. Geol. Soc. Spec. Publ. 2002, 200, 239-253. [CrossRef]

65. Siegesmund, S.; Helming, K.; Kruse, R. Complete texture analysis of a deformed amphibolite: Comparison between neutron, diffraction and U-stage data. J. Struct. Geol. 1994, 16, 131-142. [CrossRef]

66. Zucali, M.; Barberini, V.; Voltolini, M.; Ouladdiaf, B.; Chateigner, D.; Mancini, L.; Lutterotti, L. Quantitative 3D microstructural analysis of naturally deformed amphibolite from the Southern Alps (Italy): Microstructures, CPO and seismic anisotropy from a fossil extensional margin. Geol. Soc. Lond. Spec. Publ. 2015, 409, 201-222. [CrossRef]

67. Frassi, C.; Musumeci, G.; Zucali, M.; Mazzarini, F.; Rebay, G.; Langone, A. The Cotoncello Shear Zone (Elba Island, Italy): The deep root of a fossil oceanic detachment fault in the Ligurian ophiolites. Lithos 2017, 278-281, 445-463. [CrossRef]

68. Zucali, M.; Voltolini, M.; Ouladdiaf, B.; Mancini, L.; Chateigner, D. The 3D quantitative lattice and shape preferred orientation of a mylonitised metagranite from Monte Rosa (Western Alps): Combining neutron diffraction texture analysis and synchrotron X-ray microtomography. J. Struct. Geol. 2014, 63, 91-105. [CrossRef]

69. Zucali, M.; Fontana, E.; Panseri, M.; Tartarotti, P.; Capelli, S.; Ouladdiaf, B. Submarine lava flow direction revealed by neutron diffraction analysis in mineral lattice orientation. Geochem. Geophys. Geosyst. 2014, 15, 765-788. [CrossRef]

70. Frischbutter, A.; Neov, D.; Scheffzük, C.; Vrána, M.; Walther, K. Lattice strain measurements on sandstones under load using neutron diffraction. J. Struct. Geol. 2000, 22, 1587-1600. [CrossRef]

71. Tartarotti, P.; Zucali, M.; Panseri, M.; Lissandrelli, S.; Capelli, S.; Ouladdiaf, B. Mantle origin of the Antrona serpentinites (Antrona ophiolite, Pennine Alps) as inferred from microstructural, microchemical, and neutron diffraction quantitative texture analysis. Ofioliti 2011, 36, 167-189.

72. Lutterotti, L.; Matthies, S.; Wenk, H.R. MAUD (Material Analysis Using Diffraction): A user friendly Java program for Rietveld Texture Analysis and more. In Proceedings of the Twelfth International Conference on Textures of Materials (ICOTOM-12); Szpunar J.A., Ed.; NRC Research Press: Ottowa, ON, Canada, 1999; Volume 2, pp. 1599-1605.

73. Matthies, S.; Wenk, H.R.; Vinel, G.W. Some basic concepts of texture analysis and comparison of three methods to calculate orientation distributions from pole figures. J. Appl. Crystallogr. 1988, 21, 285-304. [CrossRef]

74. Viani, A.; Gualtieri, A.F.; Puente Orench, I.; Zucali, M. Texture analysis of magnesium potassium phosphate ceramics. Inst. Laue-Langevin (ILL) 2016. [CrossRef]

75. Zucali, M.; Capelli, S.; Chateigner, D.; Ouladiaf, B. Deep mantle related natural microstructures assessed by Quantitative Texture Analysis of natural rocks. Inst. Laue-Langevin (ILL) 2012. [CrossRef]

76. Zucali, M.; Benitez Perez, J.; Chateigner, D.; Gomez-Barreiro, J.; Lutterotti, L.; Ouladdiaf, B. Rheology of the lower crust: Quantitative Texture Analysis of High Pressure - High Temperature rocks from Alps and Iberian Variscan belt. Inst. Laue-Langevin (ILL) 2014. [CrossRef]

77. Babuska, V.; Cara, M. Seismic Anisotropy in the Earth; Springer: Dordrecht, The Netherlands, 1991; Volume 10, 399p.

78. Mainprice, D.; Humbert, M.; Wagner, F. Phase Transformations and Inherited ODFs Implications for Petrophysical Properties. Textures Microstruct. 1991, 14, 339-345. [CrossRef]

79. Hill, R. The Elastic Behaviour of a Crystalline Aggregate. Proc. Phys. Soc. Sect. A 1952, 65, 349-354. [CrossRef] 
80. Bachmann, F.; Hielscher, R.; Schaeben, H. Texture analysis with MTEX- Free and open source software toolbox. In Solid State Phenomena; Trans Tech Publications: Zurich, Switzerland, 2010; pp. 63-68. [CrossRef]

81. Mainprice, D.; Hielscher, R.; Schaeben, H. Calculating anisotropic physical properties from texture data using the MTEX open-source package. Geol. Soc. Lond. Spec. Publ. 2011, 360, 175-192. [CrossRef]

82. Burlini, L.; Marquer, D.; Challandes, N.; Mazzola, S.; Zangarini, N. Seismic properties of highly strained marbles from the Splügenpass, central Alps. J. Struct. Geol. 1998, 20, 277-292. [CrossRef]

83. Faccenda, M.; Bressan, G.; Burlini, L. Seismic properties of the upper crust in the central Friuli area (northeastern Italy) based on petrophysical data. Tectonophysics 2007, 445, 210-226. [CrossRef]

84. Brownlee, S.J.; Hacker, B.R.; Salisbury, M.; Seward, G.; Little, T.A.; Baldwin, S.L.; Abers, G.A. Predicted velocity and density structure of the exhuming Papua New Guinea ultrahigh-pressure terrane. J. Geophys. Res. Solid Earth 2011, 116. [CrossRef]

85. Connolly, J.A. Multivariable phase diagrams: An algorithm based on generalized thermodynamics. Am. J. Sci. 1990, 290, 666-718. [CrossRef]

86. pyWerami (v. 0.25) - A Stand-Alone Program to Make Countour-3D Plot from Data File Generated by the PerpleX Program WERAMI or tci File Generated by TCInvestigator. 2017. Available online: https:/ / github.com/ondrolexa/pywerami/ (accessed on 1 November 2019).

87. Zhang, K.J.; Li, Q.H.; Yan, L.L.; Zeng, L.; Lu, L.; Zhang, Y.X.; Hui, J.; Jin, X.; Tang, X.C. Geochemistry of limestones deposited in various plate tectonic settings. Earth-Sci. Rev. 2017, 167, 27-46. [CrossRef]

88. Holland, T.J.B.; Powell, R. An internally consistent thermodynamic data set for phases of petrological interest. J. Metamorph. Geol. 1998, 16, 309-344. [CrossRef]

89. Holland, T.J.; Powell, R. An improved and extended internally consistent thermodynamic dataset for phases of petrological interest, involving a new equation of state for solids. J. Metamorph. Geol. 2011, 29, 333-383. [CrossRef]

90. Cloos, M. Lithospheric buoyancy and collisional orogenesis: Subduction of oceanic plateaus, continental margins, island arcs, spreading ridges, and seamounts. Geol. Soc. Am. Bull. 1993, 105, 715-737. [CrossRef]

91. Fisher, N.I.; Lewis, T.; Embleton, B.J. Statistical Analysis of Spherical Data; Cambridge University Press: Cambridge, UK, 1993; 329p. [CrossRef]

92. Chateigner, D. Reliability criteria in quantitative texture analysis with experimental and simulated orientation distributions. J. Appl. Crystallogr. 2005, 38, 603-611. [CrossRef]

93. Schaeben, H. Texture analysis of heterogeneous data-a farewell to F-coefficients. J. Struct. Geol. 2000, 22, 1565-1568. [CrossRef]

94. Wenk, H.R.; Takeshita, T.; Bechler, E.; Erskine, B.G.; Matthies, S. Pure shear and simple shear calcite textures. Comparison of experimental, theoretical and natural data. J. Struct. Geol. 1987, 9, 731-745. [CrossRef]

95. Burlini, L.C.M.; Rutter, E.H.; Anonymous. Preferred orientation development in hot-pressed synthetic, ultrafine-grained calcite rocks. Terra Abstr. 1993, 5, 288.

96. Casey, M.; Rutter, E.H.; Schmid, S.M.; Siddans, A.W.B.; Whalley, J.S. Texture development in experimentally deformed calcite rocks. In Textures of Materials: Proceeding of the Fifth International Conference on Textures of Materials: March 28-31, 1978, Aachen, Germany; Göttstein, G., Lücke, K., Eds.; Springer: Berlin-Heidelberg, Germany, 1978; Volume 2, pp. 231-240.

97. Trullenque, G.; Kunze, K.; Heilbronner, R.; Stünitz, H.; Schmid, S.M. Microfabrics of calcite ultramylonites as records of coaxial and non-coaxial deformation kinematics: Examples from the Rocher de l'Yret shear zone (Western Alps). Tectonophysics 2006, 424, 69-97. [CrossRef]

98. Schmid, S.M.; Casey, M.; Starkey, J. The microfabric of calcite tectonites from the Helvetic Nappes (Swiss Alps). Geol. Soc. Lond. Spec. Publ. 1981, 9, 151-158. [CrossRef]

99. Ratschbacher, L.; Wenk, H.R.; Sintubin, M. Calcite textures; examples from nappes with strain-path partitioning. J. Struct. Geol. 1991, 13, 369-384. [CrossRef]

100. Erskine, B.G.; Heidelbach, F.; Wenk, H.R. Lattice preferred orientations and microstructures of deformed Cordilleran marbles: Correlation of shear indicators and determination of strain path. J. Struct. Geol. 1993, 15, 1189-1205. [CrossRef]

101. Leiss, B.; Siegesmund, S.; Weber, K. Texture Asymmetries as Shear Sense Indicators in Naturally Deformed Mono- and Polyphase Carbonate Rocks. Textures Microstruct. 1999, 33, 61-74. [CrossRef] 
102. Pieri, M.; Burlini, L.; Kunze, K.; Stretton, I.; Olgaard, D.L. Rheological and microstructural evolution of Carrara marble with high shear strain: Results from high temperature torsion experiments. J. Struct. Geol. 2001, 23, 1393-1413. [CrossRef]

103. De Wall, H.; Bestmann, M.; Ullemeyer, K. Anisotropy of diamagnetic susceptibility in Thassos marble: A comparison between measured and modeled data. J. Struct. Geol. 2000, 22, 1761-1771. [CrossRef]

104. Ebert, A.; Herwegh, M.; Pfiffner, A. Cooling induced strain localization in carbonate mylonites within a large-scale shear zone (Glarus thrust, Switzerland). J. Struct. Geol. 2007, 29, 1164-1184. [CrossRef]

105. Demurtas, M.; Smith, S.A.; Prior, D.J.; Spagnuolo, E.; Di Toro, G. Development of crystallographic preferred orientation during cataclasis in low-temperature carbonate fault gouge. J. Struct. Geol. 2019, 126, 37-50. [CrossRef]

106. Fernández, F.J.; Brown, D.; Álvarez-Marrón, J.; Prior, D.J.; Pérez-Estaún, A. Microstructure and lattice preferred orientation of calcite mylonites at the base of the southern Urals accretionary prism. J. Geol. Soc. 2004, 161, 67-79. [CrossRef]

107. Parsons, A.J.; Law, R.D.; Lloyd, G.E.; Phillips, R.J.; Searle, M.P. Thermo-kinematic evolution of the Annapurna-Dhaulagiri Himalaya, central Nepal: The Composite Orogenic System. Geochem. Geophys. Geosyst. 2016, 17, 1511-1539. [CrossRef]

108. Wells, R.K.; Holyoke, C.W.; Newman, J.; Kronenberg, A. Lattice-preferred orientation development in experimental and natural fine-grained dolomite shear zones. J. Struct. Geol. 2019, 128, 103874. [CrossRef]

109. Leiss, B.; Weiss, T. Fabric anisotropy and its influence on physical weathering of different types of Carrara marbles. J. Struct. Geol. 2000, 22, 1737-1745. [CrossRef]

110. Barnhoorn, A.; Bystricky, M.; Burlini, L.; Kunze, K. The role of recrystallisation on the deformation behaviour of calcite rocks: Large strain torsion experiments on Carrara marble. J. Struct. Geol. 2004, 26, 885-903. [CrossRef]

111. Oesterling, N.; Heilbronner, R.; Stünitz, H.; Barnhoorn, A.; Molli, G. Strain dependent variation of microstructure and texture in naturally deformed Carrara marble. J. Struct. Geol. 2007, 29, 681-696. [CrossRef]

112. Negrini, M.; Smith, S.A.; Scott, J.M.; Tarling, M.S. Microstructural and rheological evolution of calcite mylonites during shear zone thinning: Constraints from the Mount Irene shear zone, Fiordland, New Zealand. J. Struct. Geol. 2018, 106, 86-102. [CrossRef]

113. De Bresser, J.H. Calcite c-axis textures along the Gavarnie thrust zone, central Pyrenees. Geol. Mijnb. 1989, 68, 367-375.

114. Anselmetti, F.S.; Eberli, G.P. Sonic Velocity in Carbonate Sediments and Rocks. Carbonate Seismol. 1997, 6, 53-74. [CrossRef]

115. Bassinot, F.C.; Marsters, J.C.; Mayer, L.A.; Wilkens, R.H. Velocity anisotropy in calcareous sediments from Leg 130, Ontong Java Plateau. Proc. Ocean Drill. Prog. Sci. Results 1993, 130, 663-672. [CrossRef]

116. Park, S.; Ishii, M. Near-surface compressional and shear wave speeds constrained by body-wave polarization analysis. Geophys. J. Int. 2018, 213, 1559-1571. [CrossRef]

117. Rudnick, R.L.; Fountain, D.M. Nature and composition of the continental crust: A lower crustal perspective. Rev. Geophys. 1995, 33, 267-309. [CrossRef]

(C) 2019 by the authors. Licensee MDPI, Basel, Switzerland. This article is an open access article distributed under the terms and conditions of the Creative Commons Attribution (CC BY) license (http://creativecommons.org/licenses/by/4.0/). 